\title{
Article
}

Doi 10.5943/sif/5/1/15

\section{Chemical compositions, cytotoxicity and antioxidant activity of the endophytic fungus Fusarium napiforme isolated from Psidium guajava}

\section{Chutulo EC ${ }^{1,2,3}$, Chalannavar $\mathrm{RK}^{4^{*}}$ and Pramod Kumar $\mathbf{P}^{5}$}

${ }^{1}$ Department of Studies \& Research in Microbiology, Mangalore University, Jnana Kaveri, P.G. Centre, Chikka Aluvara, Kodagu-571232, Karnataka, India

${ }^{2}$ Department of Biosciences, Mangalore University, Mangalagangotri-574199, Karnataka, India

${ }^{3}$ Department of Biology, Wolaita Sodo University, Wolaita Sodo, Ethiopia

${ }^{4}$ Department of Applied Botany, Mangalore University, Mangalagangotri-574199, Karnataka, India

${ }^{5}$ Department of Biochemistry, CSIR-Central Food Technological Research Institute, Mysuru-570020, Karnataka, India

Chutulo EC, Chalannavar RK, Pramod Kumar P 2020 - Chemical compositions, cytotoxicity and antioxidant activity of the endophytic fungus $F$. napiforme isolated from Psidium guajava L. Studies in Fungi 5(1), 332-352, Doi 10.5943/sif/5/1/15

\begin{abstract}
The bioactive secondary metabolites from the endophytic fungus Fusarium napiforme was evaluated for the cytotoxic effect and antioxidant activity. The total antioxidant capacity (TAC) of the extract was determined by 2, 2-diphenyl-1-picrylhydrazyl (DPPH), phosphomolybdate, and reducing power assay methods. The cytotoxicity of the extract was evaluated against lung adenocarcinoma (A549) cells and mouse embryo fibroblast (NIH3T3) cells by methyl thiazolyl tetrazolium (MTT) method. The major composition of the crude extract was identified by the Gas Chromatography-Mass Spectrometry (GC-MS) analysis. Estimation of the endophyte crude extract revealed a high amount of the total flavonoid content (TFC) and total phenolic content (TPC). The extract showed high cytotoxic activity against the A549 cell line with the mean cytotoxicity of $69.74 \pm 0.49 \%$. The extract did not show any cytotoxic effect against the NIH3T3 cell line. The extract exhibited high antioxidant activity as a function of the concentrations. At a test concentration of $1 \mathrm{mg} \mathrm{ml}^{-1}$, the extract showed the highest inhibition against DPPH radical at $75.4607 \% \pm 0.47688$, ferric ion reducing power at $0.882 \pm 0.0120$, and $255.434 \pm 21.404 \mathrm{AAE} / \mathrm{g}$ of the extract by phosphomolybdenum assay (PMA). There is a significant correlation between TPC and antioxidant activity at $p<0.05$. The correlation between reducing power and DPPH is significant at $p<0.01$. The major types of bioactive compounds identified by the GC-MS have shown the presence of nine major compounds. This result strongly exhibits that the endophyte $F$. napiforme can be a potential source for the formulation of natural anticancer drugs and protecting the body from oxidative damages.
\end{abstract}

Keywords - flavonoids - GC-MS analysis - lung adenocarcinoma cells - mouse embryo fibroblast cells - MTT assay - phenolics

\section{Introduction}

Fungal endophytes are fungi that inhabit internal plant tissues without harming their host (Schulz \& Boyle 2005). The endophytic interaction of fungi and the host plant extends from mutualism to latent pathogens depending on plant immunity (Strobel 2002). The endophytic fungi 
are promising sources of naturally occurring cytotoxic compounds (Danagoudar et al. 2018, Handayani et al. 2018). Endophytic microbes copy the biochemical mechanism of their host plants and produce the natural product(s) similar to the host (Venieraki et al. 2017, Fischer \& Schüffler 2018, Naik et al. 2019). There are few reports on the bioactive endophytic fungi from Psidium guajava despite its wide ethnomedicinal uses. Bioactive compounds of an endophytic fungus Phomopsis sp. (Thu et al. 2019) and four endophytic Aspergillus species (Susilawati et al. 2018) isolated from Psidium guajava showed antimicrobial activity. The endophytic fungi KL-1.1 (Okoye et al. 2015), B. ochroleuca M21 (Li et al. 2016), and Alternaria atrans (Yang et al. 2019) associated to Psidium guajava showed antiproliferative activity against cancer cell lines.

Psidium guajava L. (Myrtaceae) is a food crop and medicinal plant that grows in tropical and subtropical countries (Lim 2012, Hiwale 2015). Different parts of the plant have been used in the ethnomedicinal preparation for the treatment of different human diseases (Shu et al. 2012, Paniagua-Zambrana et al. 2020) such as diarrhea, stomach ache, wounds, cold, cough, and fever; diabetes and anthelmintic (Khare 2007, Lim 2012). In India, the species of guajava has been used for the treatment of fever, muscle spasm, and rheumatism (Morton 1987), diarrhea, piles and vomiting (Debbarma et al. 2017), jaundice, infections, hypertension, and heat stroke (Raj et al. 2018). The leaves of $P$. guajava are well investigated for the isolation of different types of natural products with antioxidant activity and antimutagenic potentials (Zahin et al. 2017). The plant is a reservoir of diverse bioactive metabolites such as pentacyclic triterpenoid (Begum et al. 2007), the cytotoxic and antioxidant guavinoside (Feng et al. 2015), psiguanins (Shao et al. 2012), phenolics, flavonoids, carotenoids, essential oils and others (Gutiérrez et al. 2008).

Fusarium napiforme, an endophytic fungus isolated from the mangrove plant, Rhizophora mucronata produced two new naphthoquinone derivatives with moderate antibacterial activity (Supratman et al. 2019). The cytotoxic compound taxol was produced by the endophytic fungus Taxomyces andreanae isolated from Pacific yew (Stierle et al. 1993). The production of yew taxol and endophytic taxol from yews as well as other plant sources are reported (Strobel 2002). Cancer is one of the increasingly deadly diseases in the entire world (Torre et al. 2016). The morbidity and mortality rate of the human population now a day increases due to the cancerous growth of the cells, particularly in low-income countries. The global cancer burden is significant and increasing (Willans \& Jankowski 2019, WHO 2020). Currently, the number of anticancer compounds isolated from endophytic fungi has been increasing (Fischer \& Schüffler 2018) and $57 \%$ of novel or analogs compounds were reported from endophytic fungi (Kumar et al. 2014). Most importantly, apart from its safety and reproducibility, the bioprospecting of natural products from the endophytic microorganisms prevent the extinction of the host plants (Aly et al. 2013).

Furthermore, the endophytic fungi isolated from medicinal plants produced important bioactive secondary metabolites in industry, agriculture, and medicine (Meena et al. 2019). Owing to this, the natural products from endophytic fungi receive increasing attention to prospecting the wide spectrum of biological potentials such as natural antioxidant activity, cytotoxic effects, antimicrobials, and anti-inflammatory activity (Gómez \& Luiz 2018). Nevertheless, the endophytic fungi remain a vastly underexplored reservoir for natural product discovery (Hillman et al. 2017). Therefore, this work aimed to identify the major chemical composition of the extract (GC-MS), evaluate the phenolic compounds, flavonoids, and in vitro antioxidant activity of the bioactive secondary metabolite isolated from endophytic F. napiforme from Psidium guajava. The cell toxic effect of the extract was also determined against lung adenocarcinoma (A549) cells and mouse embryo fibroblast (NIH3T3) cells.

\section{Materials \& Methods}

\section{Fungus culture and extract preparation}

Fungal endophyte, F. napiforme, isolated from the leaves of Psidium guajava in our previous report (Chutulo \& Chalannavar 2020, in press) was selected for this study based on its preliminary biological activity. We used the extract of $F$. napiforme culture preserved in the refrigerator. The 
crude extract was dissolved in methanol at a concentration of $1 \mathrm{mg} \mathrm{ml}^{-1}$ and filtered by Millipore filter $(0.45 \mu \mathrm{m})$ from which the working concentration was constituted (Barros et al. 2007).

\section{Total phenolic content estimation}

The total phenolic content of the crude extract was estimated with the Folin-Ciocalteau reagent method with modifications (Spanos \& Wrolstad 1990, Zahin et al. 2010). Both the fungal extract and gallic acid standard were prepared in methanol at the concentration of 10, 20, 40, 60, 80, and $100 \mu \mathrm{g} \mathrm{ml} \mathrm{m}^{-1}$ (Zahin et al. 2010). To $0.5 \mathrm{ml}$ of each extract, $2.5 \mathrm{ml}$ of $0.2 \mathrm{~N}$ FolinCiocalteau's reagent was added, mixed by gentle shaking, and kept for 5 minutes. Then, $2 \mathrm{ml}$ of $\mathrm{Na}_{2} \mathrm{CO}_{3}\left(7.5 \%\right.$, w/v) was added to the mixtures and incubated at $30^{\circ} \mathrm{C}$ for $20 \mathrm{~min}$. Three replicates were maintained per each experimental procedure. The absorbance of the sample was recorded at $765 \mathrm{~nm}$ (Zahin et al. 2017) using a UV/vis spectrophotometer. The phenolic content of the extract was estimated from the standard curve of Gallic acid and the result was expressed in Gallic acid equivalent per gram (GAE/g) of extract.

\section{Total flavonoid content determination of the extract}

The content of the total flavonoid of the endophytic fungal extract was evaluated by the $\mathrm{AlCl}_{3}$ method (Qiu et al. 2010). Quercetin equivalent (QE) was used to prepare the standard curve in different concentrations $\left(25,50,100,200\right.$, and $\left.400 \mu \mathrm{g} \mathrm{ml}^{-1}\right)$. Extract $(1 \mathrm{ml})$ was mixed with $1 \mathrm{ml}$ of 2\% Aluminum Chloride ( $\left.\mathrm{AlCl}_{3}\right)$ methanolic solution (Quettier-Deleu et al. 2000). The mixtures were incubated at room temperature for $15 \mathrm{~min}$ (Qiu et al. 2010), and the absorbance was recorded at $430 \mathrm{~nm}$ in a spectrophotometer. The content of total flavonoid was reported in QE/g of extract.

\section{Antioxidant activity evaluation of the extract}

The antioxidant activity of the endophyte extract was evaluated by the methods of DPPH, reducing power assay, and phosphomolybdenum assay (Zahin et al. 2017).

\section{Reducing power assay}

The reducing capacity of $F$. napiforme extract was determined as stated by the method in Barros et al. (2007). The crude extract and standard ascorbic acid (AA) solutions were prepared into different working concentrations $\left(25,50,100,200\right.$, and $400 \mu \mathrm{g} \mathrm{ml}^{-1}$ ). From this extract preparation, $2.5 \mathrm{ml}$ was mixed with $2.5 \mathrm{ml}$ of $200 \mathrm{mM}$ sodium phosphate buffer (pH 6.6) and 2.5 $\mathrm{ml}$ of $1 \%$ potassium ferricyanide. The mixture of extract and standard preparation was incubated at $50^{\circ} \mathrm{C}$ for $20 \mathrm{~min}$. After $2.5 \mathrm{ml}$ of $10 \%$ trichloroacetic acid $(\mathrm{w} / \mathrm{v})$ was added, the mixture was centrifuged at $2000 \mathrm{rpm}$ for $10 \mathrm{~min}$ (REMI R-8M centrifuge) (Barros et al. 2007). The upper layer ( $5 \mathrm{ml}$ ) was mixed with $5 \mathrm{ml}$ of Milli-Q water and $1 \mathrm{ml}$ of $0.1 \%$ ferric chloride, and the absorbance value was read at $700 \mathrm{~nm}$ using a spectrophotometer (ThermoFisher SCIENTIFIC MULTISKAN G0). The assay was performed in quadruplicate and the result was presented in mean values \pm standard deviations. The regression analysis was used to determine the $\mathrm{IC}_{50}$ values for the extract and the standard.

\section{DPPH assay for free radical scavenging (FRS) activity}

The free radical scavenging (FRS) activity of the endophyte extract was evaluated by DPPH antioxidant assay. The methanolic fungus extract was prepared in different dilutions (100, 200, 400, 600 , and $800 \mu \mathrm{g} \mathrm{ml}^{-1}$ ) and the DPPH solution was prepared in methanol according to Chan et al. (2007). To $1 \mathrm{ml}$ extract preparations from each dilution, $2 \mathrm{ml} \mathrm{DPPH}$ was added in an aluminum foil covered taste tubes and incubated in dark at room temperature for 30 minutes. The experimental preparations were performed in triplicate and the absorbance was measured at $517 \mathrm{~nm}$ in a spectrophotometer (MeRCK Spectroquant ${ }^{\circledR}$ Prove 300 ). The percentage of free radical scavenging activity was calculated by the formula:

$$
\% \text { Free radical scavenging activity }=\left[\left(\mathrm{A}_{\mathrm{c}}-\mathrm{A}_{\mathrm{s}}\right) / \mathrm{A}_{\mathrm{c}} \times 100\right]
$$


Where $A_{c}$ is the absorbance of control; $A_{s}$ is the absorbance of the sample (extract). The $\mathrm{IC}_{50}$ value required to reduce half the concentration of DPPH radical was calculated.

\section{Antioxidant capacity determination by phosphomolybdenum method}

The total antioxidant activity of the extract was determined by the method of phosphomolybdenum assay according to Prieto et al. (1999) with little modification. The fungus extract stock solution was prepared in $1 \mathrm{mg} \mathrm{ml}^{-1}$ concentration in methanol and filtered by $0.45 \mu \mathrm{m}$ pore size Millipore filter paper from which the working solution was prepared by diluting in distilled water. The phosphomolybdate reagent was prepared by mixing $100 \mathrm{ml}$ of each of $(0.6 \mathrm{M}$ $\mathrm{H}_{2} \mathrm{SO}_{4}, 28 \mathrm{mM}$ Sodium phosphate, and $4 \mathrm{mM}$ of Ammonium molybdate) in a brown bottle. The final volume was made $300 \mathrm{ml}$ of reagent. Ascorbic acid was dissolved in distilled water and the standard solution was prepared in different concentrations $\left(100,200,400,600\right.$, and $\left.800 \mu \mathrm{g} \mathrm{ml}^{-1}\right)$ at the time of recording the reading. From this standard solution, $400 \mu \mathrm{l}$ was pipetted into a borosilicate test tube (covered with Aluminum foil) to which $4 \mathrm{ml}$ of phosphomolybdate reagent was added. The contents of the mixture covered in aluminum foil were incubated in a water bath at $95^{\circ} \mathrm{C}$ for 90 minutes. The blank was prepared by mixing $4 \mathrm{ml}$ of the reagent with $400 \mu \mathrm{l}$ methanol and incubated in the same condition. After the incubation period, the mixture was allowed to cool to room temperature and the absorbance was measured at $695 \mathrm{~nm}$ (ThermoFisher SCIENTIFICMULTISKAN G0 spectrophotometer) against the blank. The antioxidant activity of the extract was reported in ascorbic acid equivalents per gram (AAE/g) of extract.

\section{Cytotoxic effect of the extract}

The cytotoxicity of the extract was assessed using Methyl Thiazolyl Tetrazolium (MTT) assay (Mosmann 1983). The crude extract was prepared at four series of threefold dilutions starting from $1000 \mu \mathrm{g} \mathrm{ml}^{-1}$ at the upper limit (Monks et al. 1991). The cytotoxic effect of the extract was evaluated against the lung carcinoma (A549) cell line and Mouse embryo fibroblast (NIH3T3) cell line.

\section{Cells and culture conditions}

Lung adenocarcinoma (A549) cells and Mouse embryo fibroblast (NIH3T3) cells were purchased from National Center for Cell Sciences (NCCS), Pune. They were cultured in Dulbecco's Modified Eagle's Medium (DMEM) amended with 10\% FBS and 1\% antibioticantimycotic solution. Cells were maintained at $37^{\circ} \mathrm{C}$ and in a $5 \% \mathrm{CO}_{2}$ humid atmosphere (Monks et al. 1991) and were used for the experiments at least after three consecutive passages.

\section{Assessment of cytotoxicity}

Cells were seeded into 96 well microtiter plates at a seeding density of 5000 cells/well. After adherence, they were treated with different concentrations of the extract, viz., 37.037, 111.11, 333.33, and $1000 \mu \mathrm{g} \mathrm{ml}^{-1}$ (Monks et al. 1991). After 48 hrs post-incubation with extract, MTT reagent was added to the wells and incubated at $37^{\circ} \mathrm{C}$ for $4 \mathrm{hrs}$. The formed Formazan crystals were solubilized using DMSO and absorbance was recorded at $570 \mathrm{~nm}$ using a multimode microplate reader (FluoSTAR Omega, BMG Labtech) (Sahana \& Rekha 2019). The crude extract presenting cytotoxic activity against cancer cell lines was evaluated for the potent concentration that inhibited $50 \%$ of cancer cell growth $\left(\mathrm{IC}_{50}\right)$ in the average of a triplicate experiment. Percentage cytotoxicity of the extract was calculated considering untreated cell control (Kim et al. 2017).

\section{Gas chromatography-mass spectrometry (GC-MS) analysis}

The Perkin Elmer AUTOSYSTEM X (Perkin Elmer, USA) GC-MS was used for the analysis of the major components of the endophyte crude extract responsible for the biological activity of the extract. The GC-MS instrument was operated in the following conditions: An initial temperature set to $60^{\circ} \mathrm{C}$. The oven temperature increases to $250^{\circ} \mathrm{C}$ with a rate of $3^{\circ} \mathrm{C} / \mathrm{min}$. The electron multiplier voltage was 1150 V (Pansanit \& Pripdeevech 2018). The ion source temperature 
was set at $230^{\circ} \mathrm{C}$ and the quadrupole temperature was set to $250^{\circ} \mathrm{C}$. Helium was used as the carrier gas with a flow rate of $1 \mathrm{ml} / \mathrm{min}$ and with column $30.0 \mathrm{~m} \times 250 \mu \mathrm{m}$, solvent delay $4.00 \mathrm{~min}$. The ionization voltage was $70 \mathrm{eV}$. The sample was injected in split mode as 50:1. Mass spectral scan range was set at 29-300 (m/z) (Pansanit \& Pripdeevech 2018). The metabolites were identified by comparing the mass spectra to the GC-MS library spectra using the NIST database.

\section{Statistical data analysis}

The experiments were performed independently and the results were presented as mean \pm SD. The antioxidant activity of the extract was determined from the regression analysis of the standard curve plotted by using the Microsoft Excel spreadsheet. The $\mathrm{IC}_{50}$ values for antioxidant activity and cytotoxicity were calculated by non-linear regression equation using GraphPad Prism 5 software. Pearson's correlation between the antioxidant activity and total phenolic and flavonoid content was analyzed by using SPSS 25 at a 95\% confidence interval (Samaga et al. 2014).

\section{Results}

\section{Total phenolic content determination of extract}

The total phenolic content of the extract was determined spectrophotometrically from the standard curve of Gallic acid absorbance. The crude extract contains a significant amount of phenolic content. Based on calculation from a Gallic acid standard curve (Fig. 1), the total phenolic content of the extract was $23.5035443 \pm 0.10208786 \mathrm{GAE} / \mathrm{g}$ of extract.

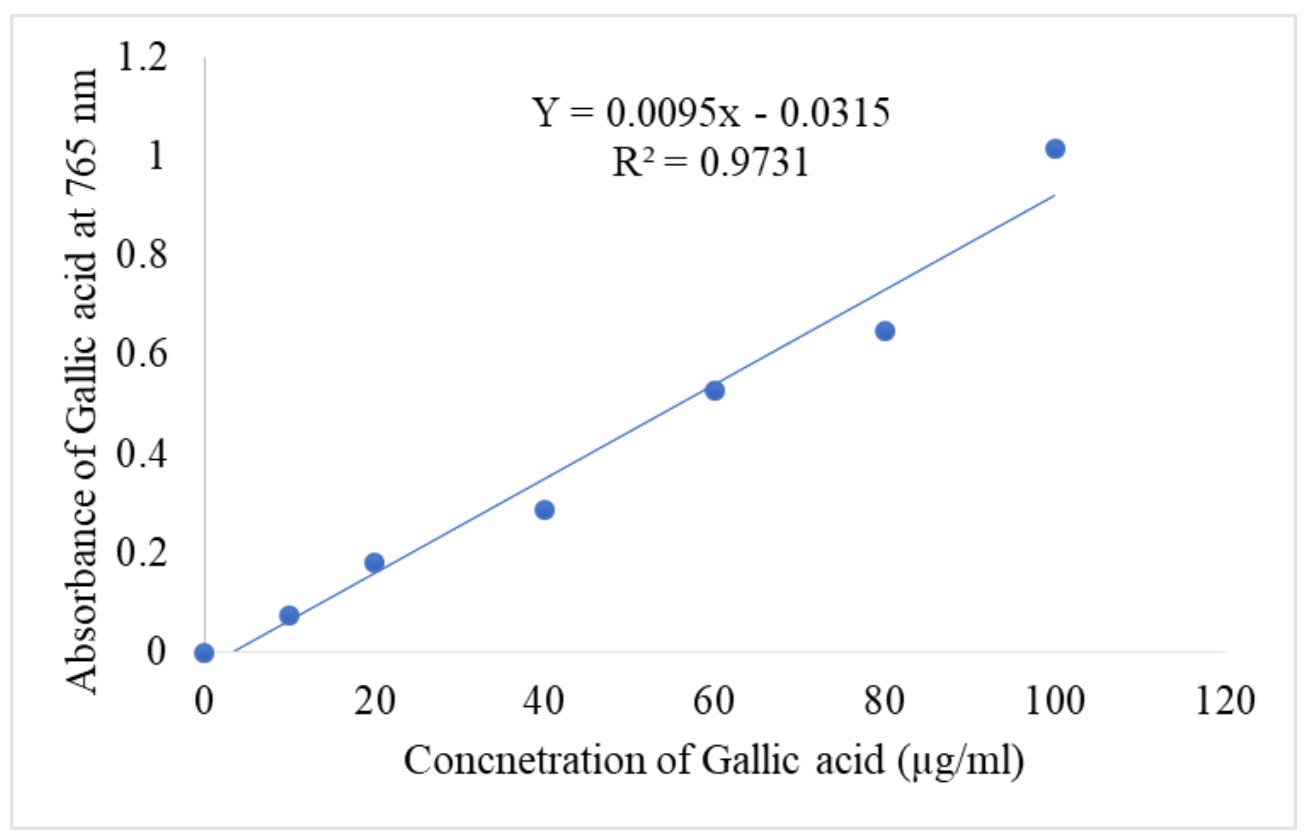

Fig. 1 - Gallic acid standard curve for the total phenolic content determination of the crude extract of the endophytic fungus.

\section{Total flavonoid estimation of the extract}

The flavonoid content of the crude extract was determined spectrophotometrically. The content of the total flavonoid of the extract was computed from the standard curve of quercetin (Fig. 2). The concentration of the total flavonoid content of the crude extract was 18.2591023 $\pm 0.10434413 \mathrm{QE} / \mathrm{g}$ of extract.

\section{Antioxidant activity of the endophyte extract}

The antioxidant activity of the extract was evaluated by DPPH assay, phosphomolybdate assay, and ferric ion reducing power assay methods (Fig. 7). 


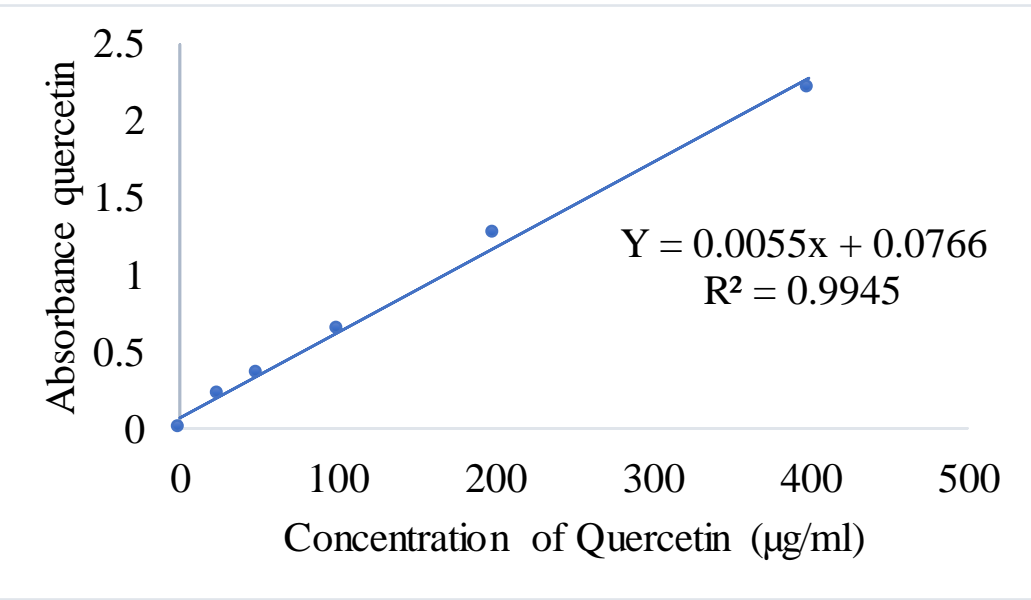

Fig. 2 - Quercetin standard curve for determination of total flavonoid content of the endophytic extract.

\section{Reducing power activity}

The reducing potential of the crude extract was evaluated spectrophotometrically from the standard curve of ascorbic acid absorbance (Fig. 3). The extract of the endophyte F. napiforme showed increased reducing capacity with the increase in the concentration of the fungal extract (Fig. 3).

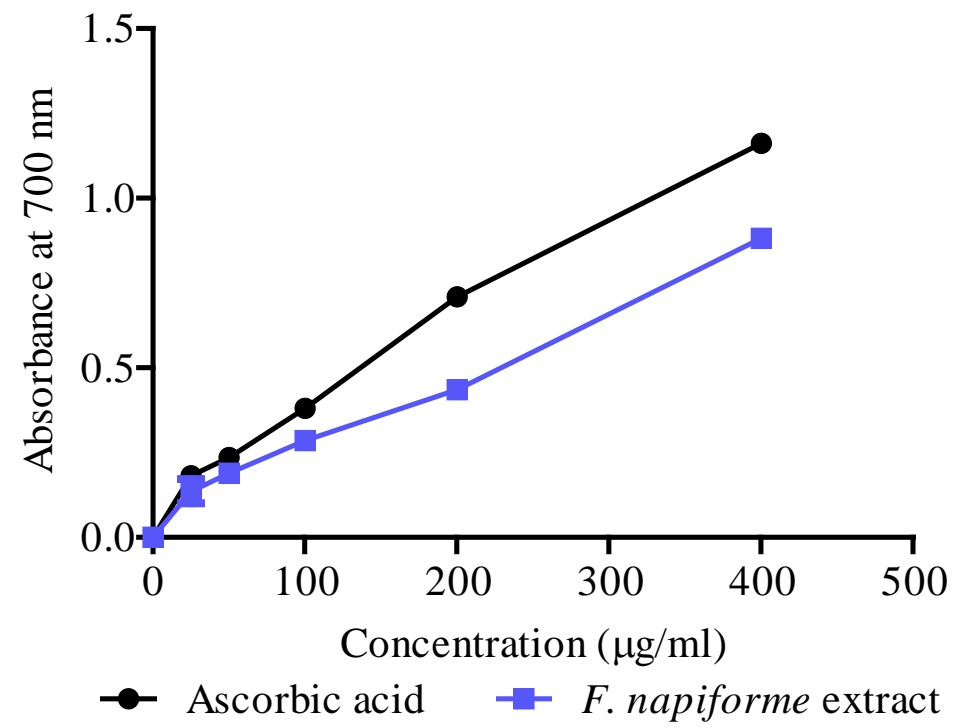

Fig. 3 - Reducing power activity of the endophyte extract and ascorbic acid standard. The blue line and the black line showing the increasing absorbance of the endophytic F. napiforme extract and standard ascorbic acid respectively.

The endophytic fungus extract showed a significant reducing power, which is very much closer to the standard (Fig. 3). At a high concentration of $400 \mu \mathrm{g} \mathrm{ml}^{-1}$, the extract and the standard ascorbic acid had a reducing capacity of $0.882 \pm 0.0120$ and $1.162 \pm 0.00974$ respectively. At low concentration $\left(25 \mu \mathrm{g} \mathrm{ml}^{-1}\right)$, the ferric ion reducing capacity of the crude extract was $0.136 \pm 0.0357$ and the ascorbic acid was $0.182 \pm 0.00765$ respectively (Table 1 ). At low concentration, the extract showed lower reducing power activity in comparison to the standard antioxidant compound (Fig. 7). 
Table 1 Antioxidant activity evaluation of the extract by reducing power assay $(n=4)$

\begin{tabular}{lll}
\hline \multicolumn{3}{c}{ Reducing power absorbance (mean \pm SD) } \\
\hline Concentration $\left(\boldsymbol{\mu g ~ \mathbf { ~ m l } ^ { - 1 } )}\right.$ & F. napiforme extract & \multicolumn{1}{c}{ Ascorbic acid } \\
\hline 25 & $0.136 \pm 0.0357$ & $0.182 \pm 0.00765$ \\
50 & $0.190 \pm 0.0118$ & $0.236 \pm 0.00829$ \\
100 & $0.286 \pm 0.00746$ & $0.380 \pm 0.0079$ \\
200 & $0.436 \pm 0.00874$ & $0.710 \pm 0.0183$ \\
400 & $0.882 \pm 0.0120$ & $1.162 \pm 0.00974$ \\
$\mathrm{IC}_{50}\left(\mu \mathrm{g} \mathrm{ml}^{-1}\right)$ & 204.6 & 176.2 \\
$\mathrm{R}^{2}$ & 0.9457 & 0.9812 \\
\hline
\end{tabular}

*Mean ferric reducing absorbance of the fungal extract and standard in quadruplicate experiments.

\section{DPPH radical scavenging capacity of the extract}

The free radical scavenging activity of the methanol fraction of the crude extract is shown in Figs 4 \& 7 . The endophyte crude extract exhibited high free radical scavenging activity (75.4607 $\pm 0.47688 \%$ ) (Table 2). The crude extract of the endophyte showed strong DPPH radical scavenging activity. At $1 \mathrm{mg} \mathrm{ml}^{-1}$ concentration, the extract and ascorbic acid (AA) have exhibited the free radical scavenging activity with an $\mathrm{IC}_{50}$ values of $299.4 \mu \mathrm{g} / \mathrm{ml}\left(\mathrm{R}^{2}=0.9627\right)$ and $384.1 \mu \mathrm{g}$ $\mathrm{ml}^{-1}\left(\mathrm{R}^{2}=0.9705\right)$ respectively. The extract has demonstrated greater antioxidant activity than that of the standard antioxidant vitamin C, particularly at lower concentrations (Fig. 4).

Table 2 The free radical scavenging potential of the endophyte extract $(n=3)$

\begin{tabular}{|c|c|c|}
\hline \multirow{2}{*}{ Concentration $\left(\mu \mathrm{g} \mathrm{ml}^{-1}\right)$} & \multicolumn{2}{|c|}{ The mean free radical scavenging activity (\%)* } \\
\hline & Ascorbic acid & F. napiforme extract \\
\hline 100 & $8.99687 \pm 3.903429$ & $46.6765 \pm 1.92949$ \\
\hline 200 & $24.84552 \pm 2.341544$ & $57.6048 \pm 1.34830$ \\
\hline 400 & $55.11759 \pm 1.243202$ & $64.1053 \pm 1.40160$ \\
\hline 600 & $62.33139 \pm 0.540178$ & $69.0450 \pm 0.73659$ \\
\hline 800 & $78.43973 \pm 0.374230$ & $72.5955 \pm 0.64701$ \\
\hline 1000 & $91.04513 \pm 1.383641$ & $75.4607 \pm 0.47688$ \\
\hline
\end{tabular}

*The percent inhibition capacity of endophyte extract by DPPH (Mean \pm SD)

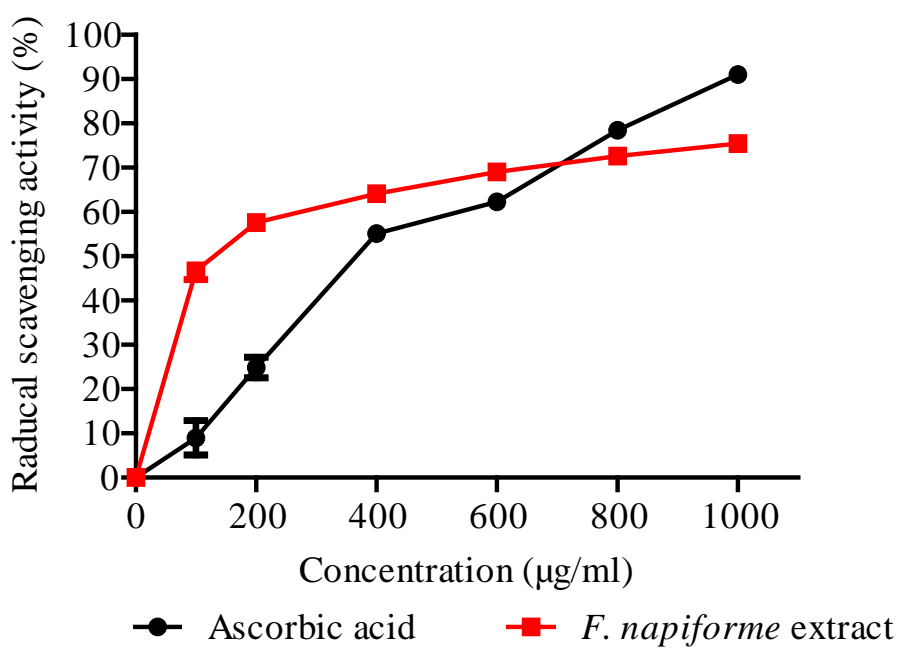

Fig. 4 - The total antioxidant activity of the endophytic extract and the standard ascorbic acid by DPPH free radical scavenging assay. Redline and the blackline showing the increasing trend of the antioxidant activity of the endophytic fungal extract and the standard ascorbic acid respectively. 


\section{Phosphomolybdenum assay}

The total antioxidant capacity of the endophyte crude extract determined by spectrophotometer from the standard curve of ascorbic acid (Fig. 5) and presented as ascorbic acid equivalent/gram (AAE/g) of the extract (Table 3).

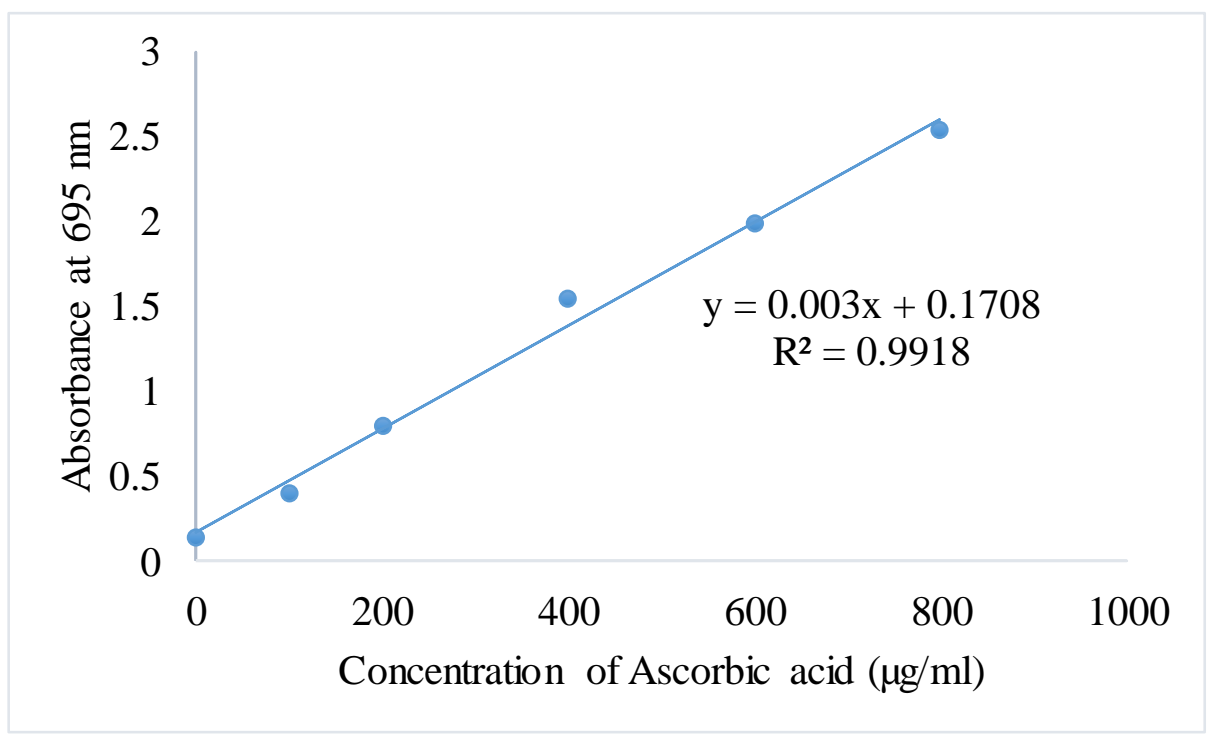

Fig. 5 - Ascorbic acid standard curve for total antioxidant evaluation by phosphomolybdenum method.

Table 3 Estimation of total antioxidant capacity (TAC) by phosphomolybdate $(n=3)$

\begin{tabular}{ll}
\hline Concentration $\left(\boldsymbol{\mu g} \mathbf{~ m l}^{-\mathbf{1}}\right)$ & Total antioxidant capacity $(\mathrm{AAE} / \mathbf{g}) *$ \\
\hline 100 & $16.217 \pm 2.484$ \\
200 & $43.869 \pm 2.511$ \\
400 & $85.853 \pm 3.916$ \\
600 & $173.405 \pm 16.904$ \\
800 & $255.434 \pm 21.404$ \\
$\mathrm{IC}_{50}\left(\mu \mathrm{g} \mathrm{ml}^{-1}\right)$ & 492.8 \\
$\mathrm{R}^{2}$ & 0.9573 \\
\hline
\end{tabular}

* The amount of TAC reported in Mean \pm SD of triplicate measurements.

The extract showed increasing antioxidant activity in a concentration-dependent function (Fig. 6). At low concentration, the extract had the TAC of 16.217 \pm 2.484 (AAE/g) whereas the amount of TAC of the extract at higher concentration, at $800 \mu \mathrm{g} \mathrm{ml}^{-1}$, was $255.434 \pm 21.404$ (AAE/g). The crude extract of $F$. napiforme and ascorbic acid revealed antioxidant capacity with $\mathrm{IC}_{50}$ values of $492.8 \mu \mathrm{g} \mathrm{ml}^{-1}\left(\mathrm{R}^{2}=0.9573\right)$ and $371.4 \mu \mathrm{g} \mathrm{ml}^{-1}\left(\mathrm{R}^{2}=0.9766\right)$ respectively. At 0.8 $\mathrm{mg} \mathrm{ml}^{-1}$ concentration, the extract showed moderate total antioxidant activity (Table 3 ). The extract showed a concentration-dependent increase in the TAC against the damaging free radical.

\section{Correlation between total phenolic and flavonoid content, and antioxidant activity}

There was a significant correlation between TPC and antioxidant activity (DPPH \& RPA) at $p<0.05$. The correlation between RPA and DPPH is significant at $p<0.01$ (Table 5). The correlation between TFC and antioxidant activity (DPPH \& RPA) was not significant whereas the observed correlation between TFC and PMA was weak. 


\section{Cytotoxicity of the extract}

The extract of $F$. napiforme presented a potent toxic activity against the lung cancer cell line (A549). The extract inhibited the proliferation of A549 cells in a concentration-dependent manner. The extract showed the cytotoxic activity to the A549 cell line with an IC 50 value of $249.8 \mu \mathrm{g} \mathrm{ml}^{-1}$ $\left(\mathrm{R}^{2}=0.9943\right)$ (Fig. 8). The mean cytotoxicity of the crude extract was $69.74 \pm 0.49 \%$ at $1.0 \mathrm{mg} \mathrm{ml}^{-1}$ concentration of the extract (Table 4). Most importantly, this extract has shown no toxicity to the mouse embryo fibroblast (NIH3T3) cell line (Table 4). Only at higher concentration (1000 $\left.\mathrm{g} \mathrm{m} \mathrm{m}^{-1}\right)$, negligible cell toxicity was observed $(6.06 \pm 0.96 \%)$ against the normal cell line (NIH3T3).

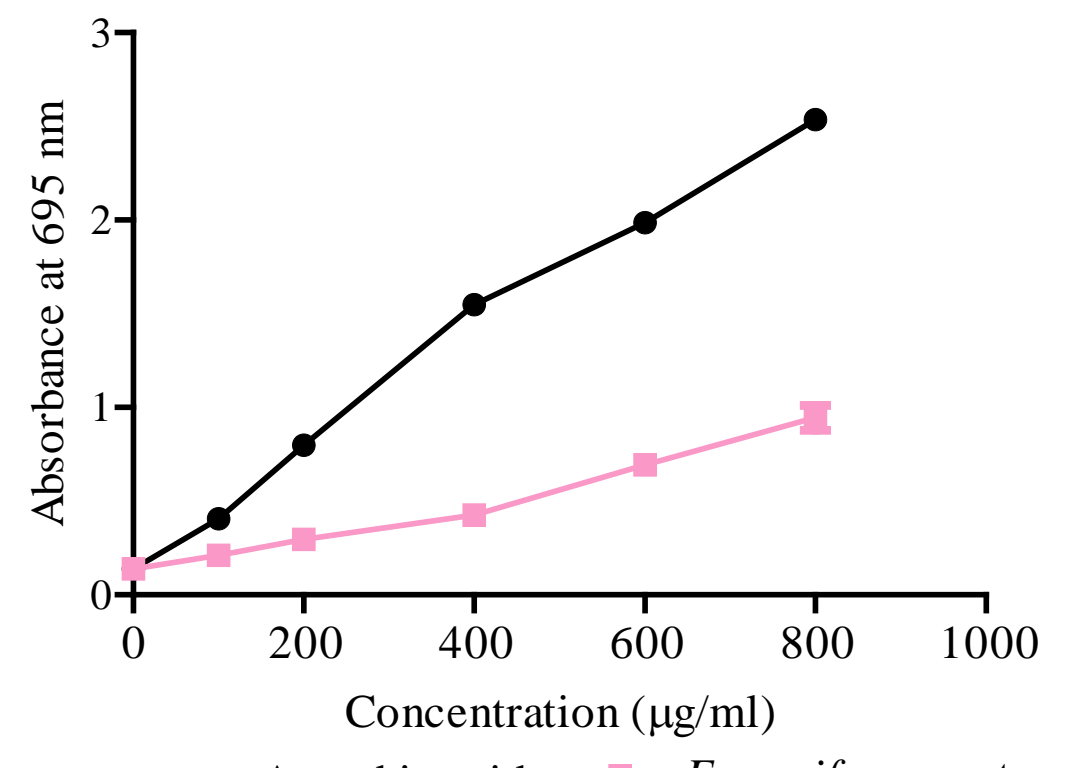

$\rightarrow$ Ascorbic acid $\quad-$ F. napiforme extract

Fig. 6 - Total antioxidant activity of the extract by phosphomolybdate assay. Pink Line and the black line showing the increasing trend of the antioxidant activity of the endophytic fungal extract and the standard ascorbic acid respectively.

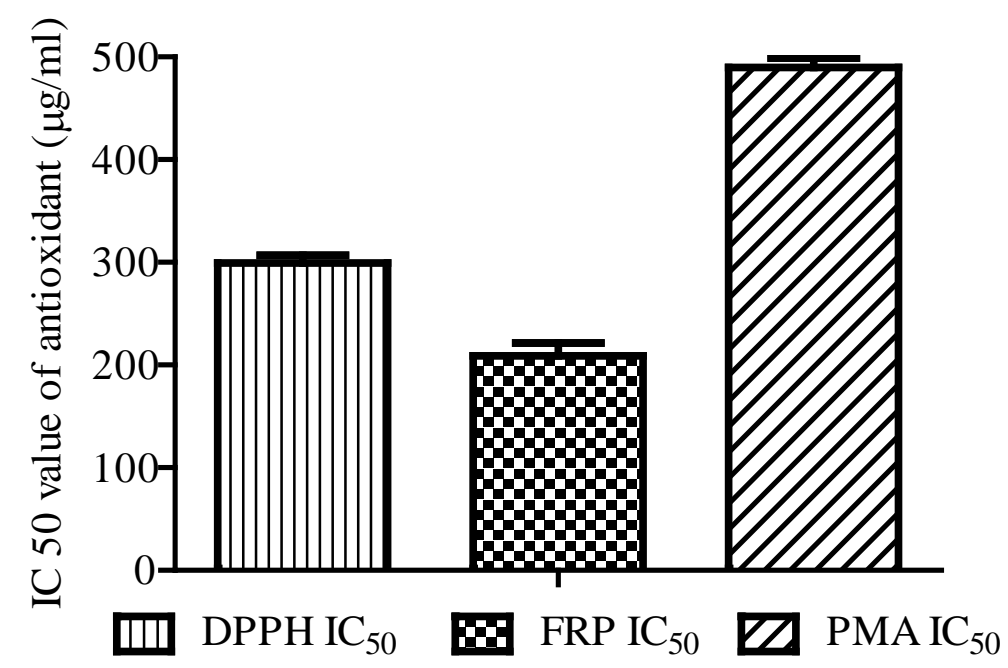

Fig. 7 - The $\mathrm{IC}_{50}$ values of antioxidant activity of the endophytic extract by DPPH, phosphomolybdenum, and reducing power assays. Vertical parallel line bar represents DPPH, square box bar represents reducing power and diagonal line bar represents the phosphomolybdenum assays. 
Table 4 Cytotoxicity test of the endophytic fungus extract assessed using MTT assay (n=3).

\begin{tabular}{lll}
\hline \multicolumn{3}{c}{ Mean cytotoxicity of the endophyte extract ${ }^{\text {ab }}$} \\
\hline Concentration $\left(\boldsymbol{\mu g ~ \mathbf { ~ m l } ^ { - 1 } )}\right.$ & ${ }^{\mathbf{a}}$ Cytotoxicity (Mean $\left.\% \pm \mathbf{S D}\right)$ & ${ }^{\mathbf{b}}$ Cytotoxicity $($ Mean $\% \pm \mathbf{S D})$ \\
\hline 37.037 & $6.32 \pm 0.51$ & $0.32 \pm 0.13$ \\
111.11 & $16.82 \pm 0.56$ & $0.91 \pm 0.19$ \\
333.33 & $46.51 \pm 1.37$ & $1.13 \pm 0.33$ \\
1000 & $69.74 \pm 0.49$ & $6.06 \pm 0.96$ \\
$\mathrm{IC}_{50}\left(\mu \mathrm{g} \mathrm{ml}^{-1}\right)$ & $249.8\left(\mathrm{R}^{2}=0.9943\right)$ & $431.5\left(\mathrm{R}^{2}=0.9504\right)$ \\
\hline
\end{tabular}

${ }^{a}$ Cytotoxicity of the extract against A549 cells; ${ }^{\mathbf{b}}$ Cytotoxicity of the extract against NIH3T3 cells.

Table 5 Pearson's correlation for quantitative determinations of antioxidant activity ${ }^{c}$

\begin{tabular}{llllll}
\hline \multicolumn{6}{c}{ Correlations between } \\
\hline Variables & DPPH & RPA & PMA & TFC & TPC \\
DPPH & 1 & & & & \\
RPA & $1.000^{* *}$ & 1 & & & \\
PMA & 0.882 & 0.880 & 1 & & \\
TFC & -0.829 & -0.831 & -0.467 & 1 & \\
TPC & $-0.998^{*}$ & $-0.998^{*}$ & -0.846 & 0.866 & 1 \\
\hline
\end{tabular}

RPA: Reducing power activity; PMA: Phosphomolybdate assay; DPPH; TFC: Total flavonoid content; and TPC: Total phenolic content.

${ }^{c} 95 \%$ confidence interval; ${ }^{* *}$ Correlation is significant at $p<0.01$; ${ }^{*}$ Correlation is significant at $p<0.05$.

The crude extract was not cytotoxic to the mouse embryo fibroblast (NIH3T3) cell line at the concentration tested (Table 4). The IC $_{50}$ value of the extract against the NIH3T3 cell line was 431.5 $\mu \mathrm{g} \mathrm{ml} \mathrm{l}^{-1}\left(\mathrm{R}^{2}=0.9504\right)$.

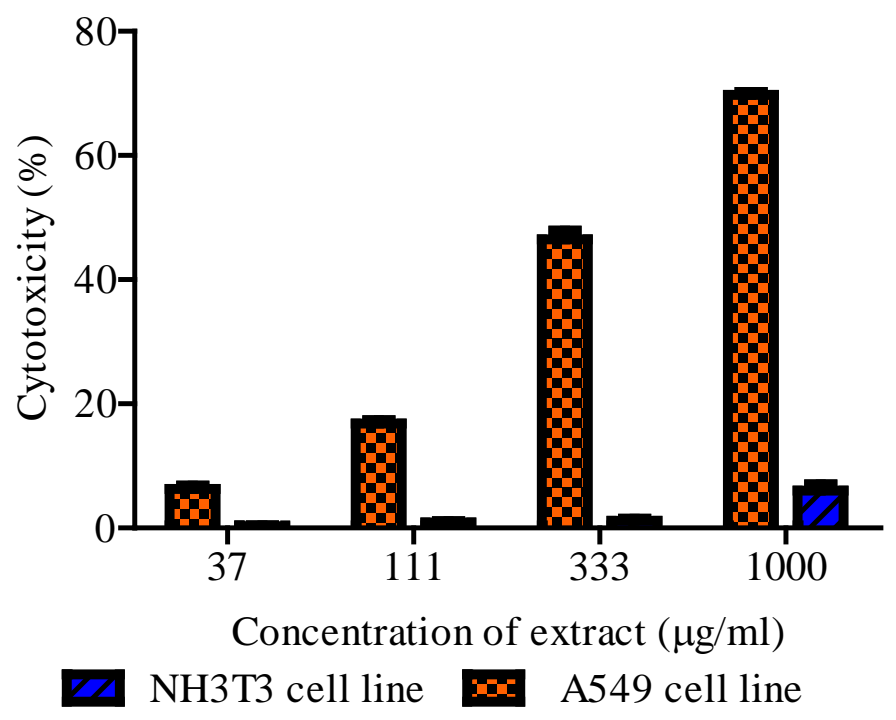

Fig. 8 - The IC $_{50}$ value for cytotoxicity of the endophytic extract against the lung adenocarcinoma (A549) cell line and mouse embryo fibroblast (NIH3T3) cell line.

\section{The major types of bioactive compounds identified from the extract}

The GC/MS analysis of the crude extract showed the presence of 9 major compounds (Fig. 9a-j). The metabolites were identified by the mass fragmentation pattern of each compound compared with the authentic compounds in the National Institute Standard and Technology (NIST) database. The major types of bioactive compounds, volatile and aliphatic constituents, identified showed the presence of aliphatic compounds and their derivatives (methyl esters). Some of the 
major representative endophytic fungal volatile metabolites identified are the aliphatic compounds such as Dichloroacetic acid, 6-ethyl-3-octyl ester; 3,4,4, Trimethyl-1-pentyn-3-ol; Benzaldehyde, 3,4- dimethyl; Phenol, 3,5-bis(1,1-dimethylethyl); Hexadecanoic acid, methyl ester; Methyl stearate; trans-13-Octadecenoic acid, methyl ester; 9,12-Octadecadienoic acid, methyl ester; 2,6-Diaminoanthraquinone, and other derivatives (Table 6).

Table 6 The major bioactive compounds identified from the crude extract

\begin{tabular}{llllll}
\hline Peak No. & RT (min) & Area $\%$ & $\mathbf{m} / \mathbf{z}$ & $\begin{array}{l}\text { Chemical } \\
\text { formula }\end{array}$ & Name of compounds identified \\
\hline 1 & 5.679 & 1.925 & 268 & $\mathrm{C}_{12} \mathrm{H}_{22} \mathrm{Cl}_{2} \mathrm{O}_{2}$ & Dichloroacetic acid, 6-ethyl-3-octyl ester \\
2 & 5.759 & 1.443 & 126 & $\mathrm{C}_{8} \mathrm{H}_{14} \mathrm{O}$ & 3,4,4-Trimethyl-1-pentyn-3-ol \\
3 & 8.515 & 1.404 & 134 & $\mathrm{C}_{9} \mathrm{H}_{10} \mathrm{O}$ & Benzaldehyde, 3,4-dimethyl- \\
4 & 11.652 & 5.214 & 206 & $\mathrm{C}_{14} \mathrm{H}_{22} \mathrm{O}$ & Phenol, 3,5-bis(1,1-dimethylethyl) \\
5 & 11.747 & 16.027 & 270 & $\mathrm{C}_{17} \mathrm{H}_{34} \mathrm{O}_{2}$ & Hexadecanoic acid, methyl ester \\
6 & 14.668 & 5.365 & 298 & $\mathrm{C}_{19} \mathrm{H}_{38} \mathrm{O}_{2}$ & Methyl stearate \\
7 & 15.133 & 15.306 & 296 & $\mathrm{C}_{19} \mathrm{H}_{36} \mathrm{O}_{2}$ & trans-13-Octadecenoic acid, methyl ester \\
8 & 15.918 & 9.815 & 294 & $\mathrm{C}_{19} \mathrm{H}_{34} \mathrm{O}_{2}$ & 9,12-Octadecadienoic acid, methyl ester \\
9 & 20.545 & 2.469 & 238 & $\mathrm{C}_{14} \mathrm{H}_{10} \mathrm{~N}_{2} \mathrm{O}_{2}$ & 2,6-Diaminoanthraquinone \\
\hline
\end{tabular}

\section{Discussion}

The plant Psidium guajava is known for its high antioxidant properties due to the presence of a high amount of phenolic compounds (Naseer et al. 2018). Thus, the plant was chosen for the investigation of the endophytic fungi with cytotoxic and antioxidant activity.

The natural product is a dependable source of therapeutic and nutritional compounds (Akpotu et al. 2017). The natural secondary metabolites are produced from plants and microorganisms. The endophyte from medicinal plants has of particular interest owing to their potential production of therapeutic compounds similar to the host plant (Venieraki et al. 2017, Naik et al. 2019). Endophytic microorganisms are inexhaustible sources for the bioprospecting of biologically active natural products with agricultural, medical, and industrial applications (Aly et al. 2013, Meena et al. 2019). Fungi, especially endophytes, are one of the endophytic microorganisms that received great attention, recently, in the search of natural pharmaceutical compounds (Gond et al. 2010).

Qiu et al. (2010) have isolated endophytic fungi Aspergillus sp. which produce flavonoids and phenolic compounds. In this report, the endophyte $F$. napiforme produced an appreciable amount of flavonoids, which could be promising sources for therapeutic and dietary antioxidants. The antioxidant potential of the natural product is generally associated with the presence of phenolic compounds in the extract. The amount of total phenol and flavonoid found in the extract were $23.5035 \pm 0.102 \mathrm{GAE} / \mathrm{g}$ of extract and $18.259 \pm 0.104 \mathrm{QE} / \mathrm{g}$ of extract respectively. Similarly, the amount of total phenol and flavonoid estimated from Phyllosticta sp. were of $18.33 \pm 0.68$ GAE/g and $6.44 \pm 1.24 \mu \mathrm{g} / \mathrm{mg}$ of QE respectively (Srinivasan et al. 2010). Theantana et al. (2012) have isolated 39 endophytic fungi from Thai Medicinal Plants of which Eupenicillium shearii CMU 18 showed the highest amount of phenolic compounds (18.25 $\pm 0.138 \mathrm{mg}$ GAE/ $100 \mathrm{ml})$. This isolate, E. shearii CMU 18, has shown high reducing power $(0.293 \pm 0.004)$. In this study, the secondary metabolite extract of $F$. napiforme contains more phenolic and flavonoids contents than E. shearii CMU 18 and Phyllosticta sp.

In this study, the endophytic fungal extract from F. napiforme was tested for the antioxidant capacity by DPPH, Reducing power assay, and Phosphomolybdenum assay methods. The endophyte $F$. napiforme has shown a potent antioxidant potential with $\mathrm{IC}_{50}$ of $299.4 \mu \mathrm{g} \mathrm{ml}^{-1}$ against DPPH radical, $492.8 \mu \mathrm{g} \mathrm{ml}^{-1}$ against Phosphomolybdte ion, and $204.6 \mu \mathrm{g} \mathrm{ml}^{-1}$ against Ferric reducing power. The ferric ion reducing capacity of the endophyte extract increased as a function of the extract concentration (Barros et al. 2007). The extract showed a very good reducing power activity that proves it can be a good source of reductant molecules. The finding of this study is in 
agreement with a similar study on Phyllosticta species, endophytic fungus, isolated from Guazuma tomentosa. Phyllosticta sp. that showed the antioxidant activity with an IC 50 value of $2030.25 \pm$ $0.81 \mu \mathrm{g} / \mathrm{ml}$ against DPPH radicals (Srinivasan et al. 2010). Our endophytic fungus showed stronger DPPH radical scavenging activity than the Phyllosticta species. Further separation of the extract into its active components would enhance the antioxidant activity of the extract. Therefore, the $F$. napiforme endophyte can be a reliable resource for the discovery of therapeutic compounds.

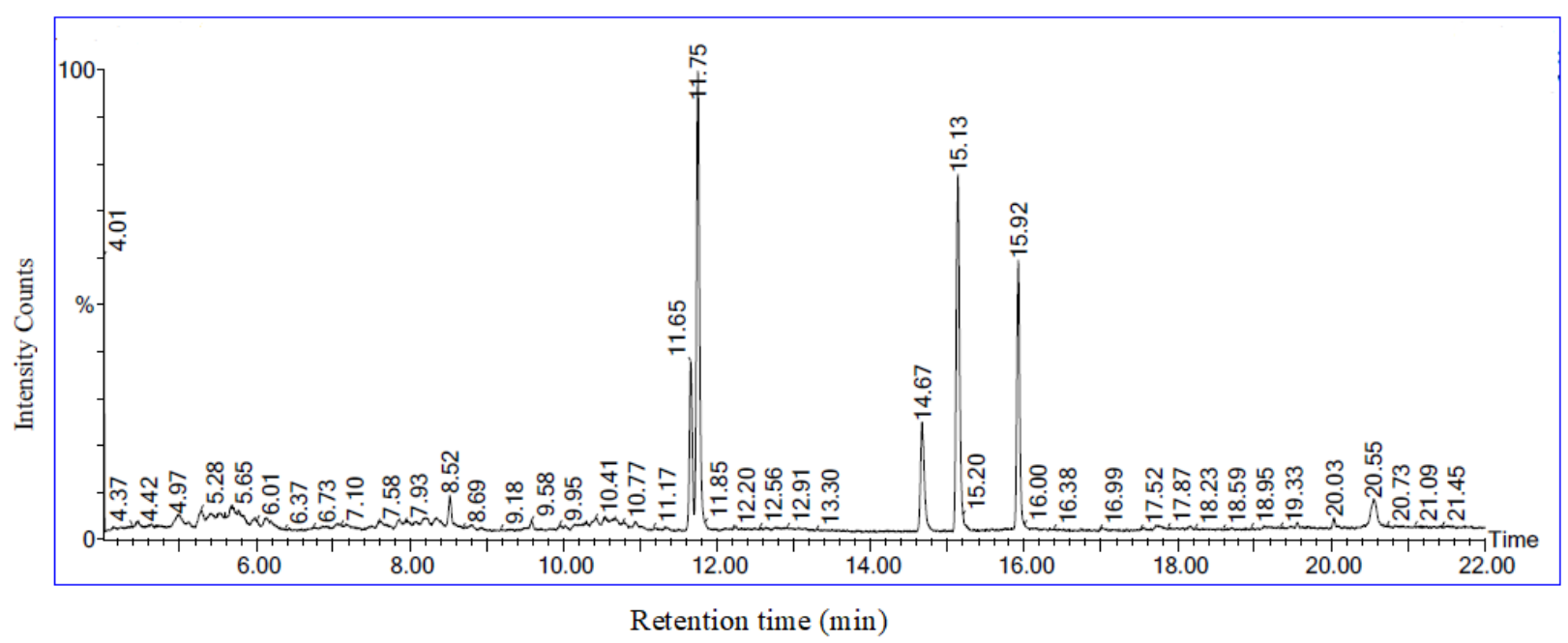

Fig. 9a - The GC-MS analysis of the crude extract of $F$. napiforme isolated from P. guajava leaves. The peaks in the figure show the retention time and the intensity count of the crude extract.

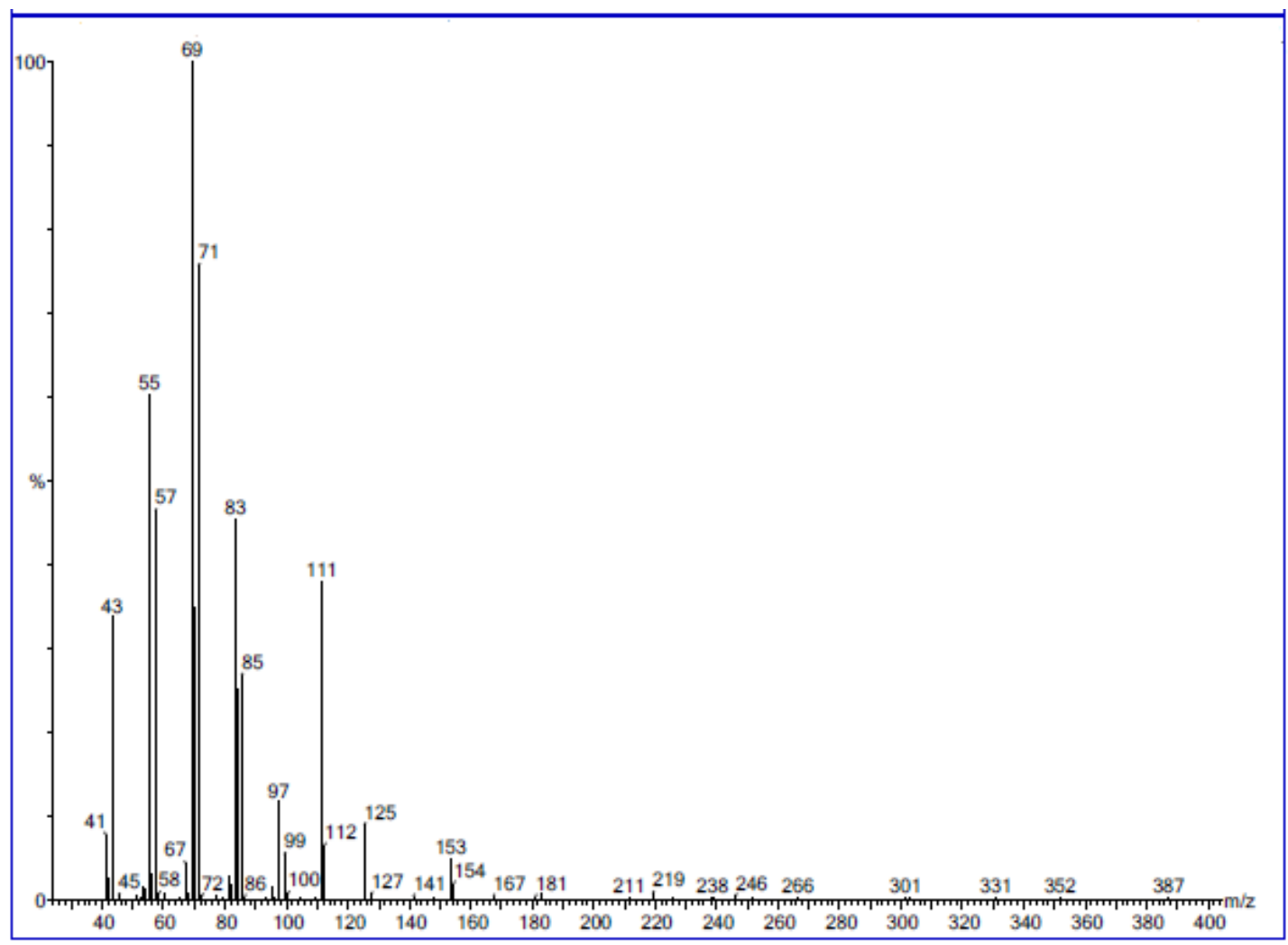

Fig. 9b - GCMS-Chromatogram of Dichloroacetic acid, 6-ethyl-3-octyl ester. The peak in the figure shows the $\mathrm{m} / \mathrm{z}$ of the crude extract at retention time 5.679 . 


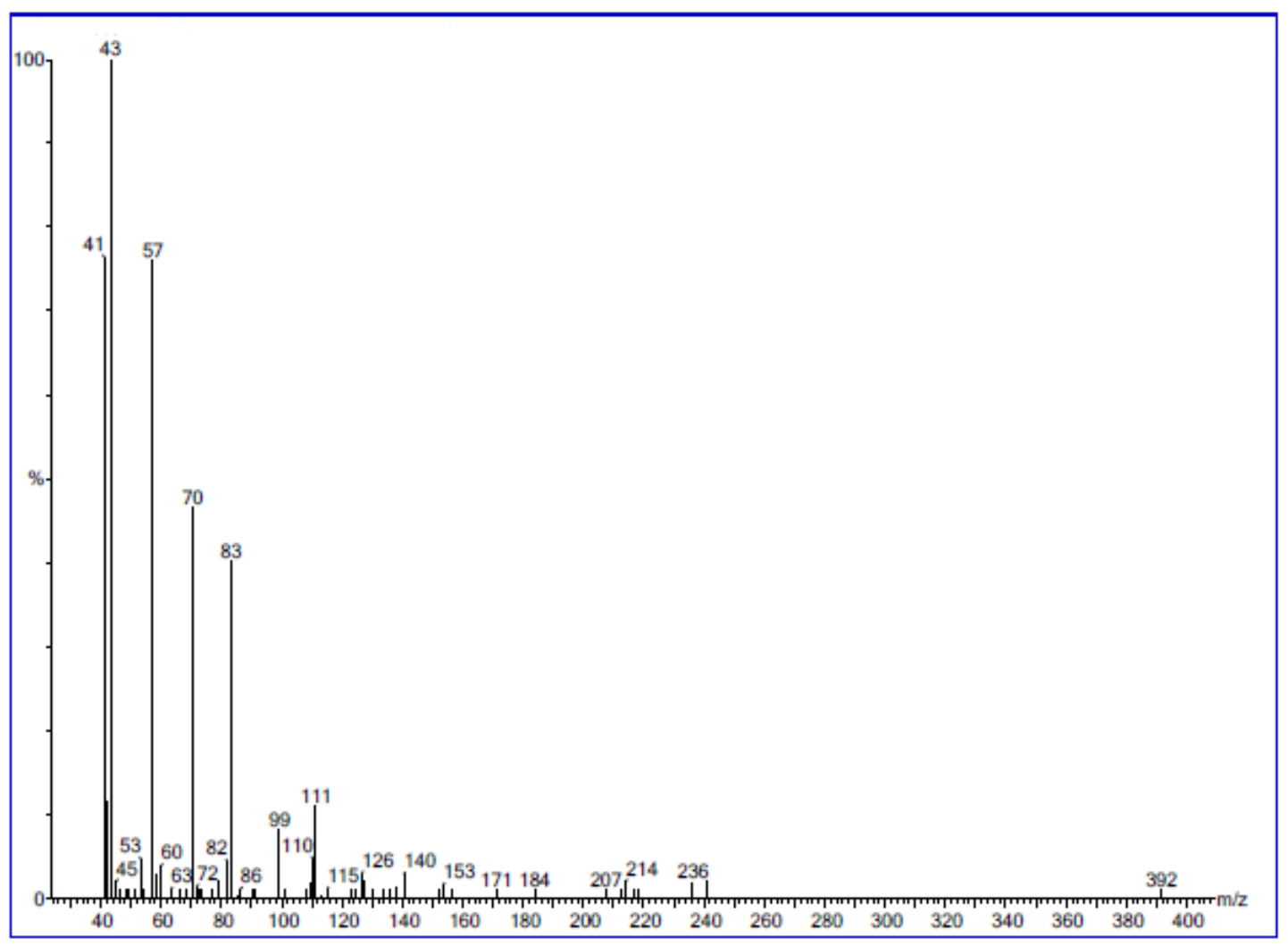

Fig. 9c - GCMS spectrum of 3, 4, 4,-Trimethyl-1-pentyn-3-ol. The peak in the figure shows the $\mathrm{m} / \mathrm{z}$ of the crude extract at retention time 5.759 .

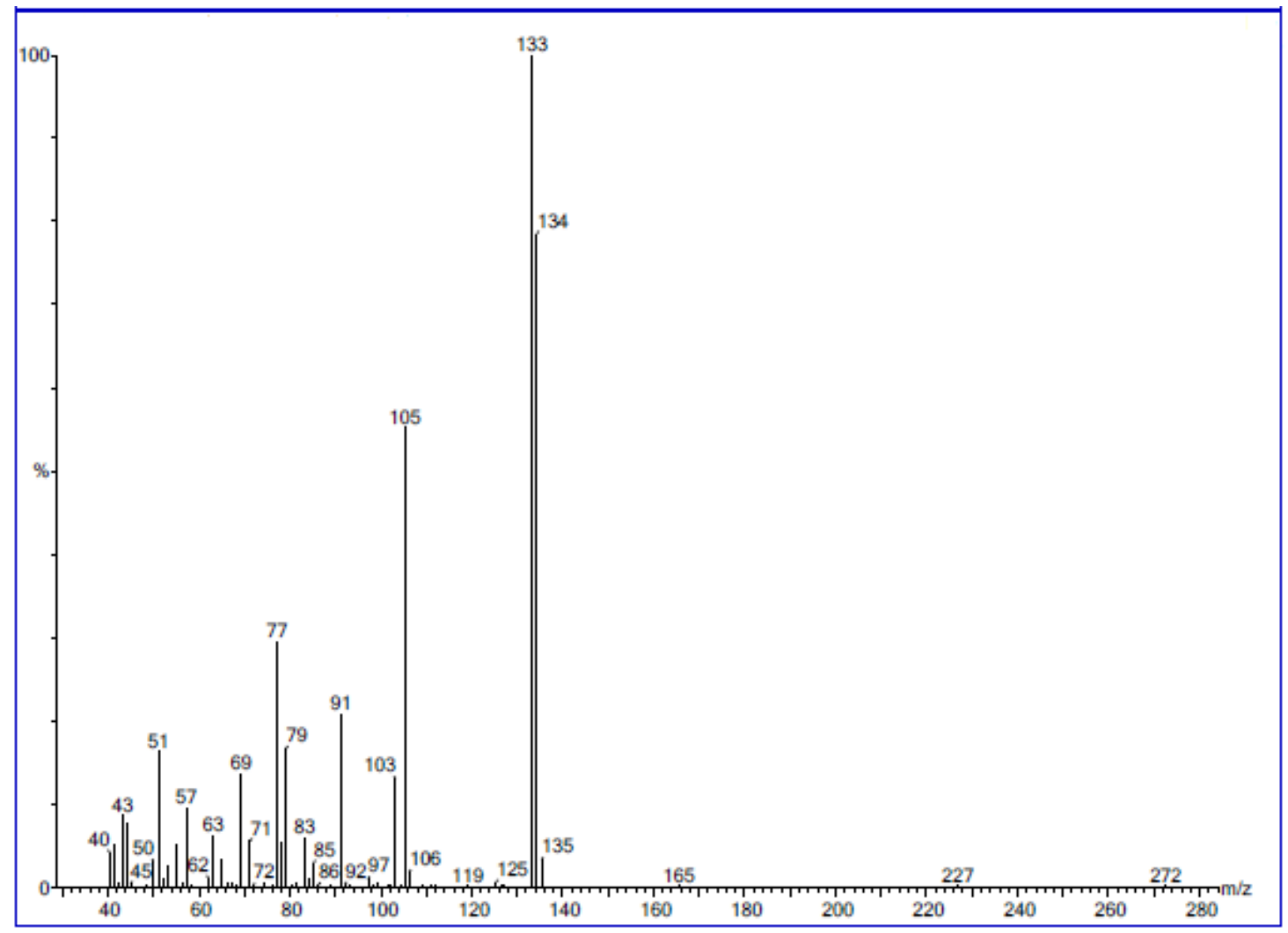

Fig. 9d - GCMS-Chromatogram of Benzaldehyde, 3, 4-dimethyl-. The peak in the figure shows the $\mathrm{m} / \mathrm{z}$ of the crude extract at retention time 8.515 . 


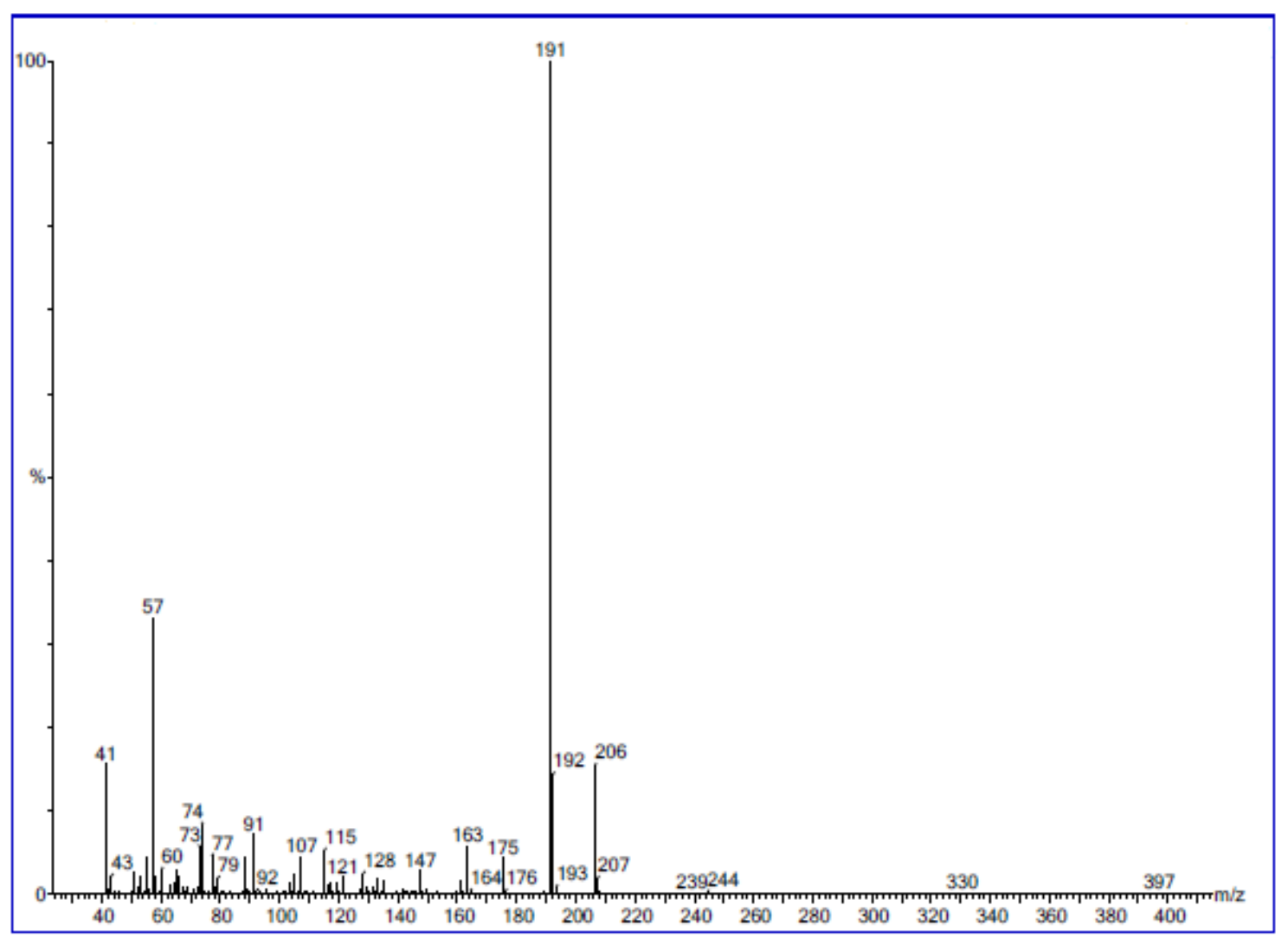

Fig. 9e - GCMS spectrum of Phenol, 3, 5-bis (1, 1-dimethylethyl). The peak in the figure shows the $\mathrm{m} / \mathrm{z}$ of the crude extract at retention time 11.652 .

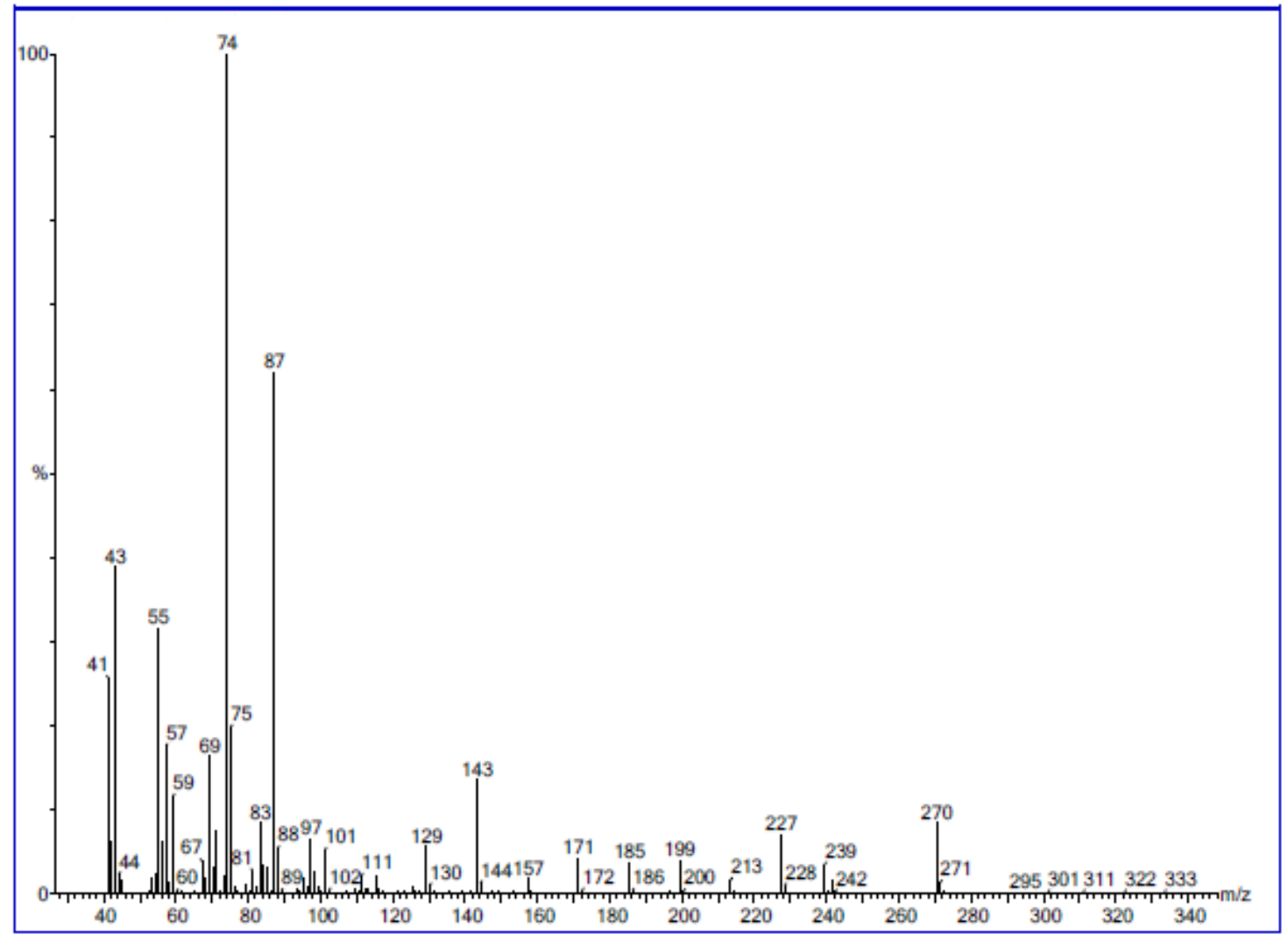

Fig. 9f - GCMS-Chromatogram of Hexadecanoic acid, methyl ester. The peak in the figure shows the $\mathrm{m} / \mathrm{z}$ of the crude extract at retention time 11.747 . 


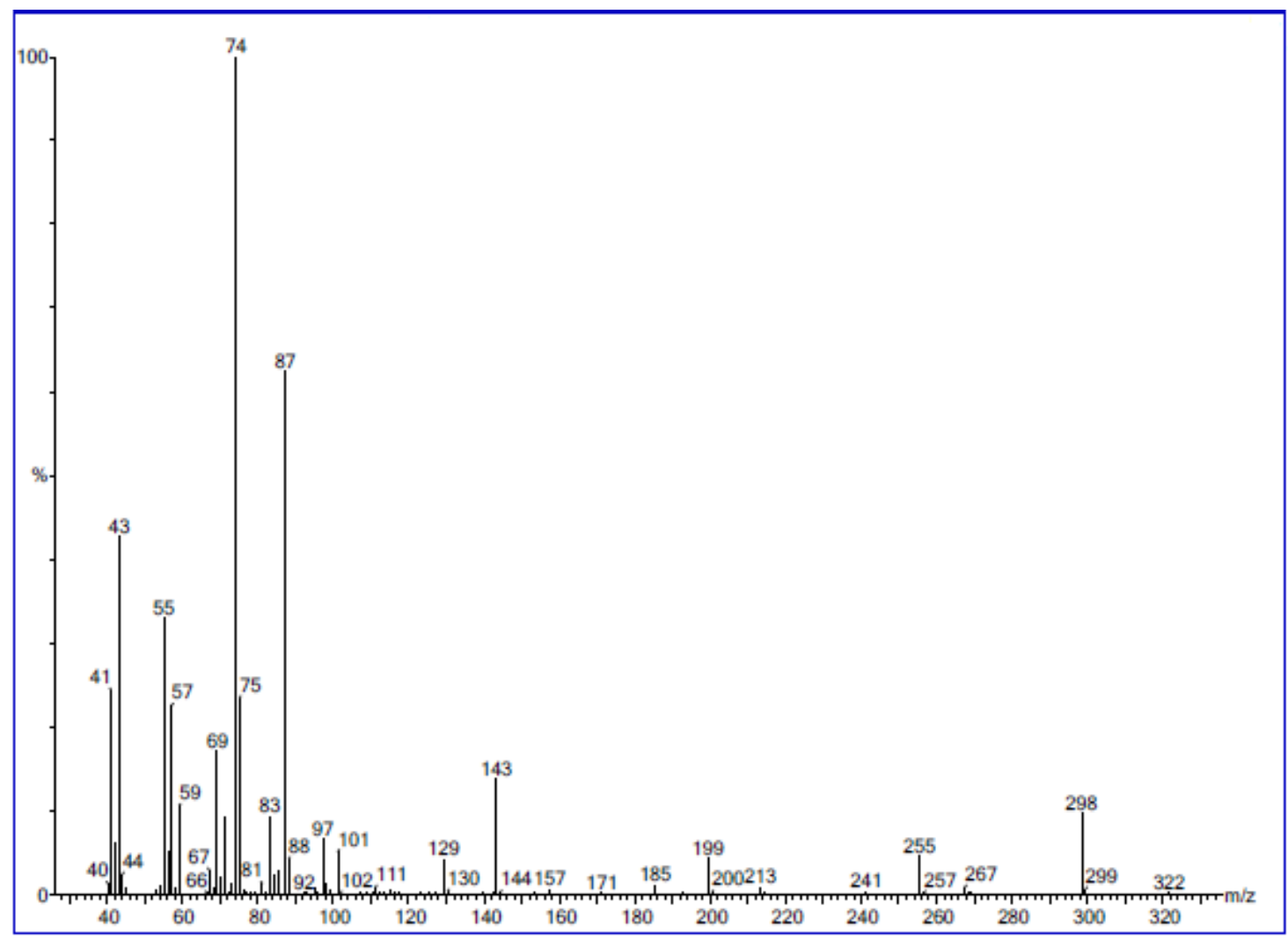

Fig. 9g - GCMS spectrum of Methyl stearate. The peak in the figure shows the $\mathrm{m} / \mathrm{z}$ of the crude extract at retention time 14.668 .

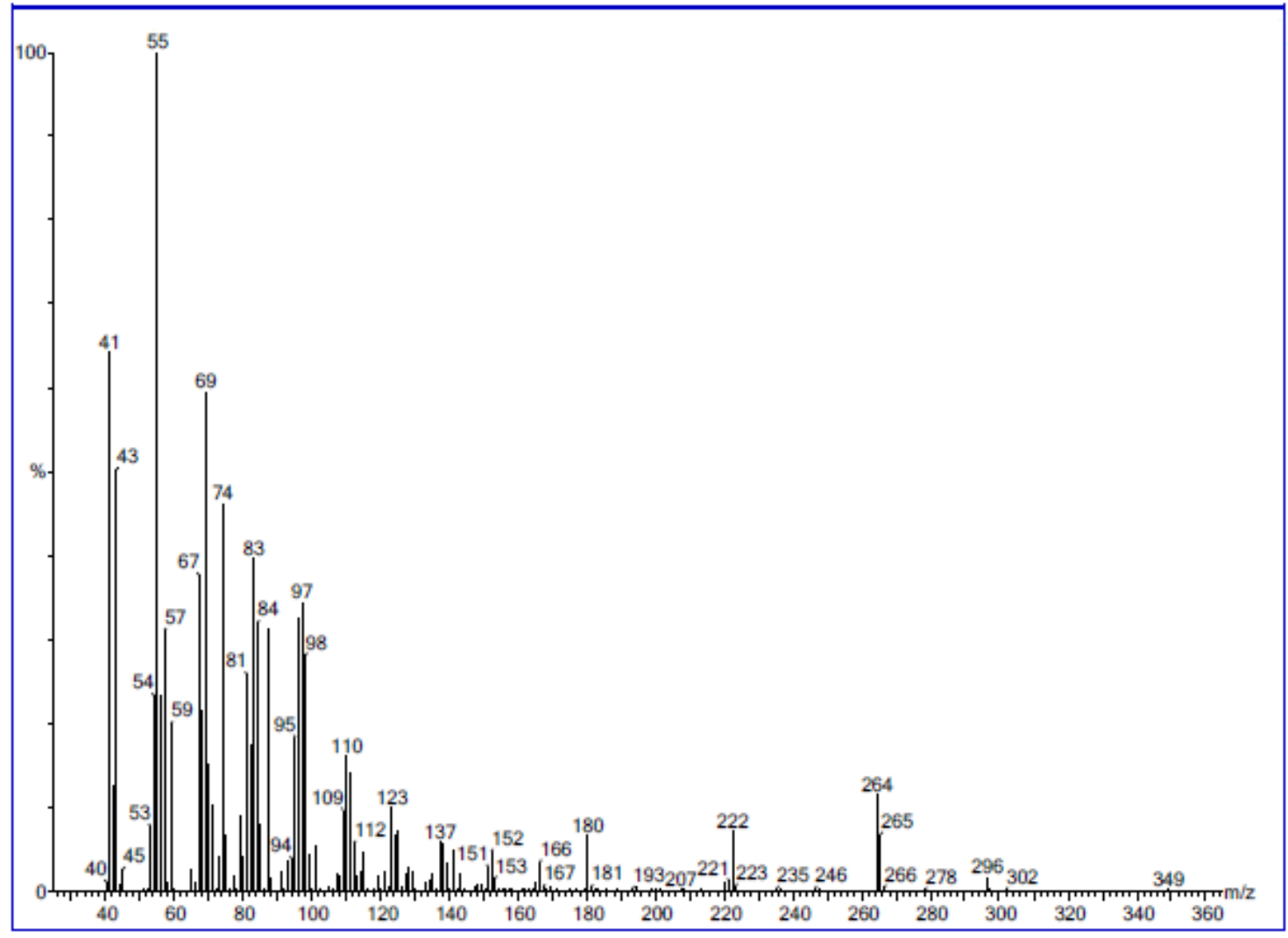

Fig. 9h - GCMS-Chromatogram of trans-13-Octadecenoic acid, methyl ester. The peak in the figure shows the $\mathrm{m} / \mathrm{z}$ of the crude extract at retention time 15.133 . 


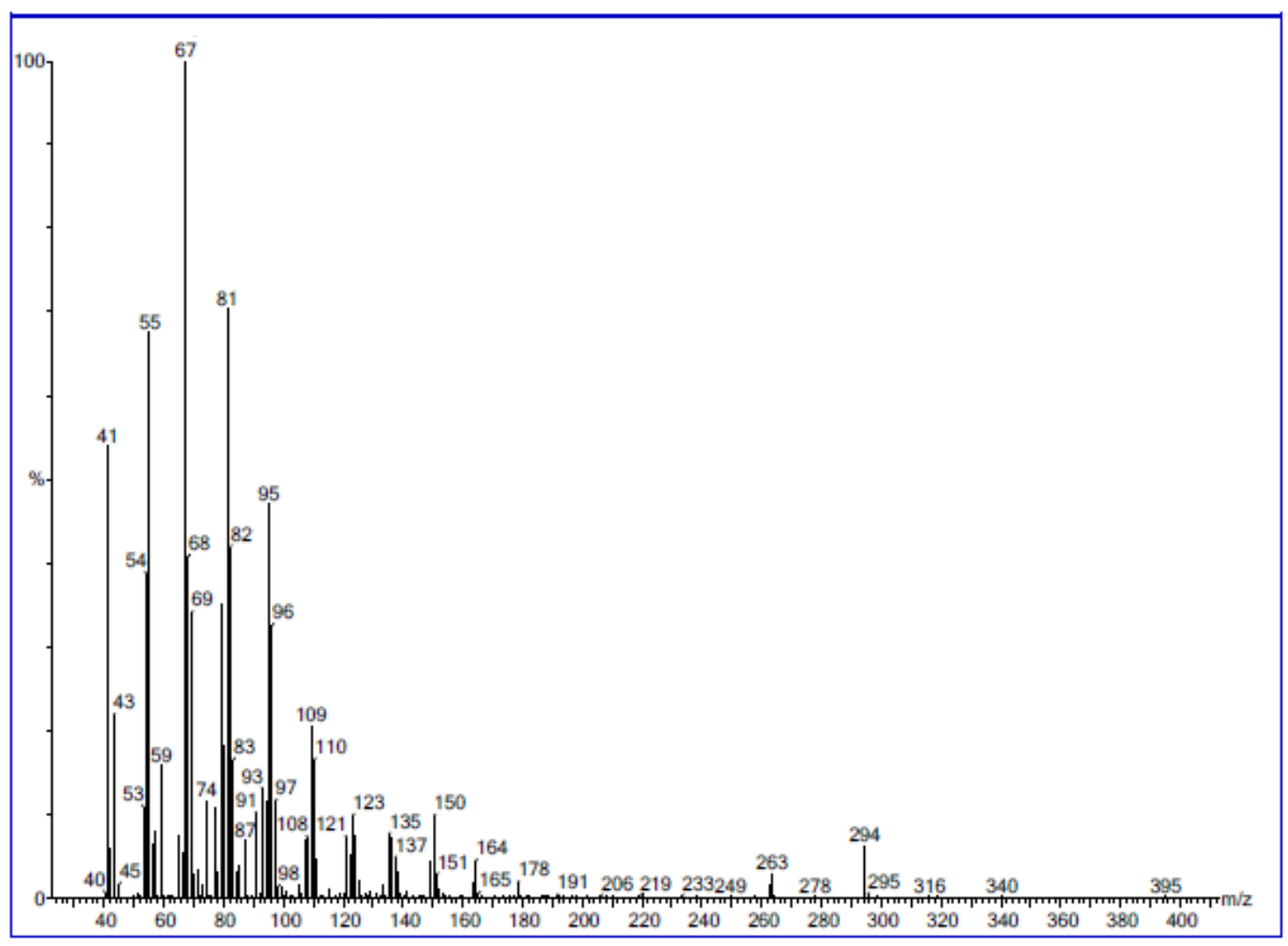

Fig. 9i - GCMS spectrum of 9, 12-Octadecadienoic acid, methyl ester. The peak in the figure shows the $\mathrm{m} / \mathrm{z}$ of the crude extract at retention time 15.918.

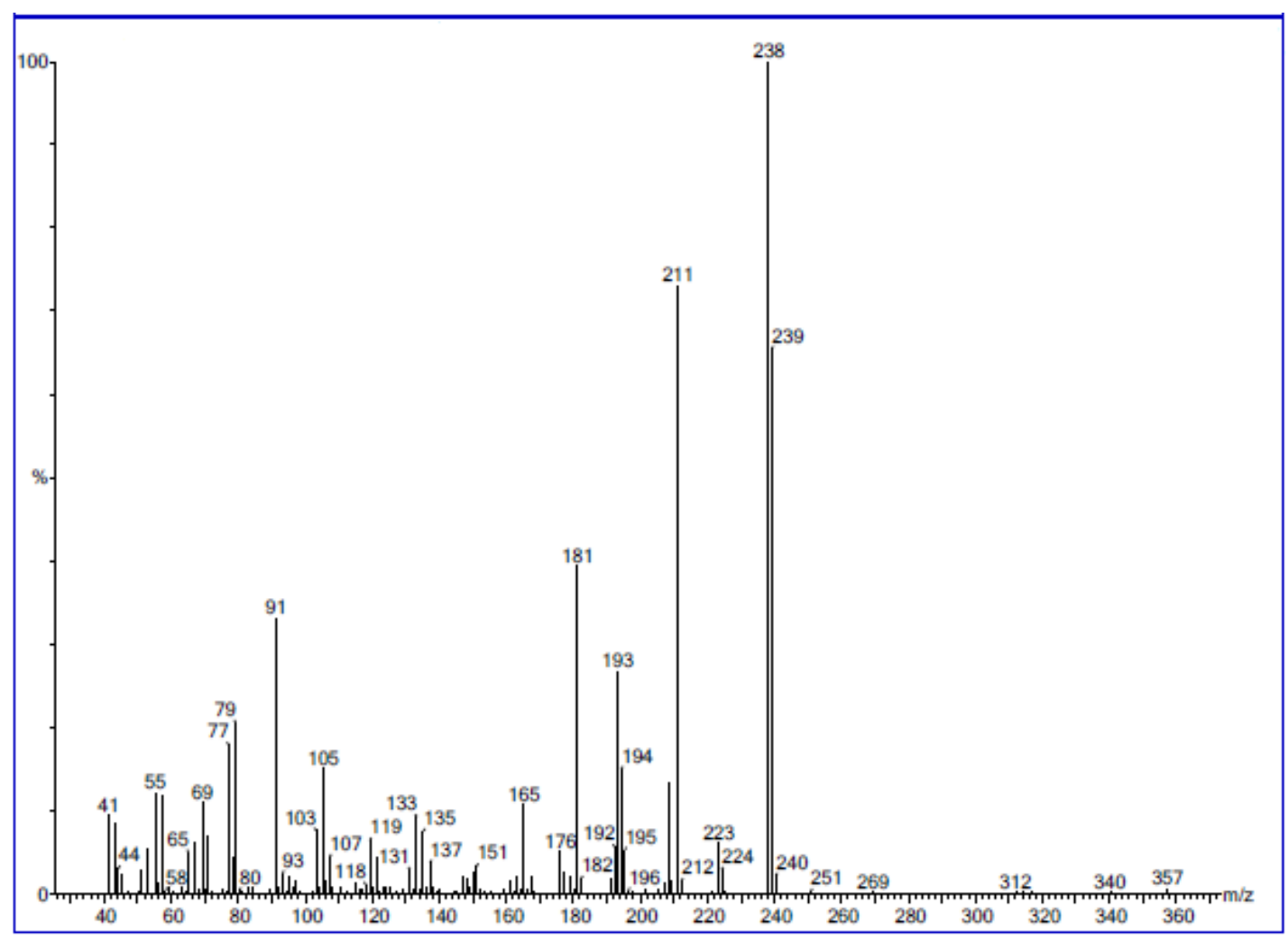

Fig. 9j - GCMS-Chromatogram of 2, 6-Diaminoanthraquinone. The peak in the figure shows the $\mathrm{m} / \mathrm{z}$ of the crude extract at retention time 20.545 . 
The natural antioxidant activity of secondary metabolites from the natural sources; microorganisms and plants, is correlated to the amounts of antioxidant compounds found in the extract (Zhou et al. 2019). In our study, we observed a significant correlation between total phenolic content and antioxidant capacity (DPPH \& RPA) at $p<0.05$. The correlation between RPA and DPPH is significant at $p<0.01$ (Table 7) whereas there was a negative and insignificant correlation between TFC and antioxidant potential (DPPH \& RPA). This may be an indication of the presence of other constituents of the compounds contributing to the antioxidant capacity of the extract besides flavonoids and phenols. Unlike the synthetic antioxidants, which can accumulate in the body and carcinogenic, antioxidants extracted from natural sources are safe and have nutritional and therapeutic values (Deng et al. 2011). The reductant present in the extract reacts with free radical ions, stabilize, and stops radical chain reactions thereby prevent the body from oxidative damage (Barros et al. 2007). Therefore, the natural antioxidant compound investigation is highly needed to prospect its nutritional and medicinal benefits from endophytic sources.

The natural products from fungi have received an increasing attraction in biotechnology to the development of novel drugs (Hillman et al. 2017). Bioprospecting the plant-associated bioactive molecules from endophytic microorganisms have of greatest importance to maintain a healthy ecology and sustainable economy (Aly et al. 2013, Vyas \& Bansal 2018). The use of plants to bioprospecting novel metabolites are limited in productivity and vulnerability to plant extinction due to cutting of tree to metabolite extraction (Gómez \& Luiz 2018, Tejesvi \& Pirttilä 2018). On the contrary, microorganisms, particularly endophytic fungi, are renewable sources for producing novel pharmaceutical molecules that are a crucial strategy to circumvent the plant extinction (Chandra 2012). This is because a metabolite originated from microbes would avoid dependence on the plant, which would reduce the cost of drugs to patients and save the environment as well (Stierle et al. 1995).

The discovery of cancer therapeutic agents from endophytic fungal extract has been prominently screened (Lopaczynski \& Zeisel 2001). Taxomyces andreanae, endophytic fungus, from Pacific Yew produced the anticancer natural compound similar to the host (Stierle et al. 1993). Uzma et al. (2018) have isolated cytotoxic compounds from endophytic Fusarium sp. In India, the same compound, taxol, was produced from Himalayan Yew associated endophytic fungus Fusarium redolen (Garyali et al. 2013) and the mangrove endophytic fungus Fusarium oxysporum (Elavarasi et al. 2012). The natural, anticancer compound, paclitaxel is produced from the pacific yew plant (Stierle et al. 1993) and their endophytic fungus associated (Strobel 2002). Above all, as to current knowledge, the endophytic fungi inside the plant have a vital role in the synthesis of bioactive metabolites. The endophyte Aspergillus terreus exhibited anticancer activity on the A549 cell line within pure and crude complexes (Goutam et al. 2017). Some endophytic Fusarium species are known producers of anticancer compounds (Aly et al. 2013). Similarly, the exopolysaccharide (EPS) from the endophytic fungus B. ochroleuca M21 showed anti-proliferative activity against liver cancer (HepG2), gastric cancer (SGC-7901) and colon cancer (HT29) cell lines ( $\mathrm{Li}$ et al. 2016). The F. napiforme endophyte in this report shown a very strong cytotoxic activity against human lung cancer (A549) cell line and it can be a potential resource to the development of effective drug molecules targeting cancer therapies. Further activity assay on different cancer cell lines in pure compounds could give more cytotoxic effect. Li et al. 2016 examined the cytotoxicity of the EPS from the endophytic fungus B. ochroleuca M21 on human liver HL-7702 cells and did not have shown cytotoxic activity. In the present study, the crude extract from endophytic $F$. napiforme shown potent cytotoxic effect against the A549 cell line. More importantly, the endophyte extract tested for the anti-proliferative activity on mouse embryo fibroblast (NIH3T3) cell line showed no cytotoxic activity. The absence of toxicity to the normal cell line is an implication of the suitability of the extract to the chemotherapeutic purpose and the safety of the metabolites to the cell. The crude extract from the endophyte fungus, F. napiforme, needs to be further evaluated in the animal model. Further purification of the crude extract is suggested for prospecting a better anti-cancer effect. 
The major bioactive compounds identified by GC-MS has shown the presence of volatile and aliphatic constituents responsible for the antioxidant activity of the crude extract (Samaga et al. 2014). Huang et al. (2007) have identified aliphatic compounds such as hexadecanoic acid methyl ester; octadecanoic acid methyl esters; 7-octadecenoic acid methyl ester) and 9, 12-Octadecadienoic acid, methyl ester in the crude extracts of the endophytic fungi isolated from Nerium oleander. Similarly, heptadecanoic acid and methyl hexadecanoic acid identified from marine Bacillus showed anti-proliferative activity against HT-29 (Human colorectal adenocarcinoma) and A549 with $\mathrm{IC}_{50}$ value $93.4 \mu \mathrm{g} / \mathrm{ml}$ and $50.04 \mu \mathrm{g} / \mathrm{ml}$ (Syed et al. 2019). The major group of compounds identified in this study may be responsible for the antioxidant capacity and cytotoxicity of the extract. As a result, the F. napiforme endophyte can be a promising resource for bioprospecting anticancer therapeutics. The purification of the crude extract and further biological activity evaluation is being carried out.

\section{Conclusion}

The crude extract of the endophytic $F$. napiforme isolated from the leaf of guajava showed significant antioxidant activity. The fungus produces a high content of total flavonoids and phenolic compounds. Apart from this, the crude extract from the fungus has a high cytotoxic effect against lung carcinoma cell line (A549) and non-toxic to normal cell line (NITHI3). Further, the GC-MS analysis of the crude extract of $F$. napiforme indicated the presence of phenols, quinone, Benzenamine, aliphatic compounds, and their derivatives. Therefore, the endophyte $F$. napiforme is a potential source for antioxidant and anticancer therapeutic formulation. More studies of the extract in different model cells are recommended to further prospect the antioxidant and cytotoxic effect in pure compounds.

\section{Acknowledgments}

We would like to thank departments of Applied Botany and Biosciences of the Mangalore University for providing laboratory facilities to conduct this research.

\section{References}

Akpotu MO, Eze PM, Abba CC, Nwachukwu CU et al. 2017 - Metabolites of endophytic fungi isolated from Euphorbia hirta growing in Southern Nigeria. Chemical Science Review and Letters 6(21), 12-19.

Aly AH, Debbab A, Proksch P. 2013 - Fungal endophytes-secret producers of bioactive plant metabolites. Pharmazie 68(7), 499-505.

Barros L, Ferreira MJ, Queirós B, Ferreira ICFR, Baptista P. 2007 - Total phenols, ascorbic acid, $\beta$-carotene and lycopene in Portuguese wild edible mushroomsand their antioxidant activity. Food Chemistry 103(2), 413 - 419.

Begum S, Ali SN, Hassan SI, Siddiqui BS. 2007 - A new ethylene glycol triterpenoid from the leaves of Psidium guajava. Natural Product Research 21(8), 742-748.

Chan EWC, Lim YY, Omar M. 2007 - Antioxidant and antibacterial activity of leaves of Etlingera species (Zingiberaceae) in Peninsular Malaysia. Food Chemistry 104(4), 1586-1593.

Chandra S. 2012 - Endophytic fungi: novel sources of anticancer lead molecules. Applied Microbiology and Biotechnology 95(1), 47-59.

Chutulo EC, Chalannavar RK. 2020 - Antimicrobial activity of Fusarium napiforme, endophytic fungus, isolated from Psidium guajava L. (white fruit). International Journal of Pharmaceutical Sciences and Research 11(11).

Danagoudar A, Joshi CG, Ravi KS, Kumar HGR, Ramesh BN. 2018 - Antioxidant and cytotoxic potential of endophytic fungi isolated from medicinal plant Tragia involucrata L. Pharmacognosy Research 10(2), 188-194.

Debbarma M, Pala NA, Kumar M, Bussmann RW. 2017 - Traditional knowledge of medicinal plants in tribes of Tripura in Northeast, India. African Journal of Traditional, Complementary 
and Alternative Medicines 14(4), 156-168.

Deng J, Cheng W, Yang G. 2011 - A novel antioxidant activity index (AAU) for natural products using the DPPH assay. Food Chemistry 125(4), 1430-1435.

Elavarasi A, Rathna GS, Kalaiselvam M. 2012 - Taxol producing mangrove endophytic fungi Fusarium oxysporum from Rhizophora annamalayana. Asian Pacific Journal of Tropical Biomedicine 2(2), S1081-S1085.

Feng XH, Wang ZH, Meng DL, Li X. 2015 - Cytotoxic and antioxidant constituents from the leaves of Psidium guajava. Bioorganic \& Medicinal Chemistry Letters 25(10), 2193-2198.

Fischer J, Schüffler A. 2018 - Bioactive compounds from tree endophytes. In: Pirttilä AM, Frank AC (eds), Endophytes of forest trees: Biology and Applications. Springer, pp. 385-440.

Garyali S, Kumar A, Reddy MS. 2013 - Taxol production by an endophytic fungus, Fusarium redolens, isolated from Himalayan yew. Journal of Microbiology and Biotechnology. 23(10), 1372-80.

Gómez OC, Luiz JHH. 2018 - Endophytic fungi isolated from medicinal plants: future prospects of bioactive natural products from Tabebuia/Handroanthus endophytes. Applied Microbiology and Biotechnology 102(21), 9105-9119.

Gond SK, Verma VC, Mishra A, Kumar A, Kharwar RN. 2010 - Role of fungal endophytes in plant protection. In: Arya A, Perello AE (eds), Management of fungal plant pathogens. CAB International, pp. 183-197.

Goutam J, Sharma G, Tiwari VK, Mishra A et al. 2017 - Isolation and characterization of "terrein” an antimicrobial and antitumor compound from endophytic fungus Aspergillus terreus (JAS2) associated from Achyranthus aspera Varanasi, India. Frontiers in Microbiology 8, 1-12.

Gutiérrez RMP, Mitchell S, Solis RV. 2008 - Psidium guajava: A review of its traditional uses, phytochemistry and pharmacology. Journal of Ethnopharmacology 117(1), 1-27.

Handayani D, Rivai H, Mulyana R, Suharti N et al. 2018 - Antimicrobial and cytotoxic activity of endophytic fungi isolated from Mangrove plant Sonneratia alba Sm. Journal of Applied Pharmaceutical Science 8(2), 049-053.

Hillman ET, Readnour LR, Solomon KV. 2017 - Exploiting the natural product potential of fungi with integrated omics and synthetic biology approaches. Current Opinion in Systems Biology 5, 50-56.

Hiwale S. 2015 - Guava (Psidium guajava). In: Sustainable horticulture in semiarid dry lands. Springer, New Delhi. pp. 213-224.

Huang WY, Cai YZ, Hyde KD, Corke H, Sun M. 2007 - Endophytic fungi from Nerium oleander L (Apocynaceae): main constituents and antioxidant activity. World Journal of Microbiology and Biotechnology 23(9), 1253-1263.

Khare CP. 2007 - Psidium guajava Linn. In: Khare CP (ed), Indian medicinal plants. Springer, New York, NY.

Kim M, Lee HJ, Randy A, Yun JH et al. 2017 - Stellera chamaejasme and its constituents induce cutaneous wound healing and anti inflammatory activity. Scientific Reports 7, 1-12.

Kumar V, Rai S, Gaur P, Fatima T. 2014 - Endophytic fungi: Novel sources of anticancer molecules. In: Verma V, Gange A (eds), Advances in endophytic research. Springer, New Delhi.

Li Y, Guo S, Zhu H. 2016 - Statistical optimization of culture medium for production of exopolysaccharide from endophytic fungus Bionectria ochroleuca and its antitumor effect in vitro. EXCLI Journal 15, 211-220.

Lim TK. 2012 - Psidium guajava. In: Edible Medicinal and Non Medicinal Plants,Vol. 3. Springer, Dordrecht. pp. 684-727.

Lopaczynski W, Zeisel SH. 2001 - Antioxidants, programmed cell death, and cancer. Nutrition Research 21, 295-307.

Meena H, Hnamte S, Siddhardha B. 2019 - Secondary metabolites from endophytic fungi: Chemical diversity and application. In: Singh B (ed), Advances in endophytic fungal research. Fungal Biology. Springer, Cham. 
Monks A, Scudiero D, Skehan P, Shoemaker R et al. 1991 - Feasibility of a high-flux anticancer drug screen using a diverse panel of cultured human tumor cell lines. Journal of the National Cancer Institute 83(11), 757-766.

Morton JF. 1987 - Fruits of warm climates. Julia F. Morton, Miami. pp.356-363.

Mosmann T. 1983 - Rapid colorimetric assay for cellular growth and survival: application to proliferation and cytotoxicity assays. Journal of Immunological Methods 65, 55-63.

Naik S, Shaanker RU, Ravikanth G, Dayanandan S. 2019 - How and why do endophytes produce plant secondary metabolites? Symbiosis 78(3), 193-201.

Naseer S, Hussain S, Naeem N, Pervaiz M, Rahman M. 2018 - The phytochemistry and medicinal value of Psidium guajava (guava). Clinical Phytoscience 4, 32.

Okoye FBC, Nworu CS, Debbab A, Esimone CO et al. 2015 - Two new cytochalasins from an endophytic fungus, KL-1.1 isolated from Psidium guajava leaves. Phytochemistry Letters 14, 51-55.

Paniagua-Zambrana NY, Bussmann RW, Romero C. 2020 - Psidium guajava L. Psidium guineense Sw. Myrtaceae. In: Paniagua-Zambrana NY, Ussmann RW (ed), Ethnobotany of the Andes. Ethnobotany of mountain regions. Springer, pp. 1-6.

Pansanit A, Pripdeevech P. 2018 - Antibacterial secondary metabolites from an endophytic fungus, Arthrinium sp. MFLUCC16-1053 isolated from Zingiber cassumunar. Mycology 9(4), 264272.

Prieto P, Pineda M, Aguilar M. 1999 - Spectrophotometric quantitation of antioxidant capacity through the formation of a phosphomolybdenum complex: specific application to the determination of vitamin E. Analytical Biochemistry 269, 337-341.

Qiu M, Xie R, Shi Y, Zhang H, Chen H. 2010 - Isolation and identification of two flavonoidproducing endophytic fungi from Ginkgo biloba L. Annals of Microbiolog 60(1), 143-150.

Quettier-Deleu C, Gressier B, Vasseur J, Dine T et al. 2000 - Phenolic compounds and antioxidant activity of buckwheat (Fagopyrum esculentum Moench) hulls and flour. Journal of Ethnopharmacology 72, 35-42.

Raj AJ, Biswakarma S, Pala NA, Shukla G et al. 2018 - Indigenous uses of ethnomedicinal plants among forest-dependent communities of Northern Bengal, India. Journal of Ethnobiology and Ethnomedicine 14, 8.

Sahana TG, Rekha PD. 2019 - A bioactive exopolysaccharide from marine bacteria Alteromonas sp. PRIM-28 and its role in cell proliferation and wound healing in vitro. International Journal of Biological Macromolecules 131, 10-18.

Samaga PV, Rai VR, Rai KML. 2014 - Bionectria ochroleuca NOTL33 - an endophytic fungus from Nothapodytes foetida producing antimicrobial and free radical scavenging metabolites. Annals of Microbiology 64(1), 275-285.

Schulz B, Boyle C. 2005 - The endophytic continuum. Mycological Research 109(6) 661-686.

Shao M, Wang Y, Huang XJ, Fan CL et al. 2012 - Four new triterpenoids from the leaves of Psidium guajava. Journal of Asian Natural Products Research 14(4), 348-354.

Shu JC, Chou GX, Wang ZT. 2012 - One new diphenylmethane glycoside from the leaves of Psidium guajava L. Natural Product Research 26(21), 1971-1975

Spanos GA, Wrolstad RE. 1990 - Influence of processing and storage on the phenolic composition of Thompson seedless grape juice. Journal of Agricultural and Food Chemistry 38(7), 15651571.

Srinivasan K, Jagadish LKK, Shenbahgaaraman R, Muthumary J et al. 2010 - Antioxidant activity of endophytic fungus Phyllosticta sp. isolated from Gauzuma tomentosa. Journal of Phytology 2(6), 37-41.

Stierle A, Strobel G, Stierle D. 1993 - Taxol and taxane production by Taxomyces andreanae, an endophytic fungus of Pacific yew. Science 260(5105), 214-216.

Stierle A, Strobel G, Stierle D, Grothaus P, Bignami G. 1995 - The search for a taxol producing microorganism among the endophytic fungi of the Pacific yew, Taxus brevifolia1. Journal of Natural Products 58(9), 1315-1324. 
Strobel GA. 2002 - Rainforest endophytes and bioactive products. Critical Reviews in Biotechnology 22(4), 315-333.

Supratman U, Hirai N, Sato S, Watanabe E et al. 2019 - New naphthoquinone derivatives from Fusarium napiforme of a mangrove plant. Natural Product Research.

Susilawati, Amalia E, Oktariana D, Khairunnisa SM. 2018 - Antibacterial activity of endophytic fungi isolated from the leaves of Jambu Biji (Psidium guajava L.); The $6^{\text {th }}$ International Conference of the Indonesian Chemical Society. Journal of Physics: Conference Series 1095(012041).

Syed CS, Sairam M, Audipudi AV. 2019 - Exploration of antibacterial and antiproliferative secondary metabolites from marine Bacillus. Journal of Microbiology Biotechnology and Food sciences 9(3), 628-633.

Tejesvi MV, Pirttilä AM. 2018 - Potential of tree endophytes as sources for new drug compounds. In: Pirttilä AM, Frank AC (eds), Endophytes of forest trees: Biology and pplications. Springer, pp. 441-462.

Theantana T, Kanjanapothi D, Lumyong S. 2012 - In vitro inhibition of lipid peroxidation and the antioxidant system of endophytic fungi from Thai medicinal plants. Chiang Mai Journal of Science 39(3), 429-444.

Thu YY, Mhon HW, Thu MM. 2019 - Bioactive compounds of an endophytic fungus Phomopsis sp. isolated from Psidium guajava L. $2^{\text {nd }}$ Myanmar Korea Conference Research Journal 1, 551-559.

Torre LA, Siegel RL, Ward EM, Jemal A. 2016 - Global cancer incidence and mortality rates and trends - an update. Cancer Epidemiology Biomarkers \& Prevention 25(1), 16-27.

Uzma F, Mohan CD, Hashem A, Konappa NM et al. 2018 - Endophytic fungi - alternative sources of cytotoxic compounds: A Review. Frontiers in Pharmacology 9, 1-37.

Venieraki A, Dimou M, Katinakis P. 2017 - Endophytic fungi residing in medicinal plants have the ability to produce the same or similar pharmacologically active secondary metabolites as their hosts. Hellenic Plant Protection Journal 10(2), 51-66.

Vyas P, Bansal A. 2018 - Fungal Endophytes: Role in Sustainable Agriculture. In: Gehlot P, Singh $\mathrm{J}$ (eds), Fungi and their role in sustainable development: Current perspectives. Springer, Singapore.

WHO 2020 - WHO report on cancer: setting priorities, investing wisely and providing care for all. World Health Organization, Geneva.

Willans R, Jankowski J. 2019 - The global cancer burden. Cancer Archives 1(1), 1-4.

Yang Z, Dan W, Li Y, Peng G et al. 2019 - Antifungal metabolites from Alternaria atrans: An endophytic fungus in Psidium guajava. Natural Product Communications, 1-5.

Zahin M, Ahmad I, Aqil F. 2017 - Antioxidant and antimutagenic potential of Psidium guajava leaf extracts. Drug and Chemical Toxicology 40(2),146-153.

Zahin M, Aqil F, Ahmad I. 2010 - Broad spectrum antimutagenic activity of antioxidant active fraction of Punica granatum L. peel extracts. Mutation Research-Genetic Toxicology and Environmental Mutagenesis 703(2), 99-107.

Zhou W, Jiang X, He P, Sun Z, Xie B. 2019 - Antioxidant activity correlation analysis of Procyanidins from China cultivars Litchi Pericarp. Science Journal of Analytical Chemistry 7(1), 27-31. 